\title{
1 Amazonian run-of-river dam reservoir impacts underestimated: 2 Evidence from a Before-After Control-Impact study of freshwater 3 turtle nesting areas
}

Andrea Bárcenas-García ${ }^{1,2} \mid$ Fernanda Michalski $^{1,2,3}$ | James P. Gibbs ${ }^{4}$ | Darren Norris ${ }^{1,2,5 *}$

$6{ }^{1}$ Postgraduate Programme in Tropical Biodiversity, Federal University of Amapá, Macapá,

7 Amapá, Brazil

$8{ }^{2}$ Ecology and Conservation of Amazonian Vertebrates Research Group, Federal University of

9 Amapá, Macapá, Amapá, Brazil

$10{ }^{3}$ Instituto Pró-Carnívoros, Atibaia, São Paulo, Brazil

$11{ }^{4}$ Department of Environmental Biology, State University of New York, Syracuse, NY, USA

$12{ }^{5}$ Coordenação de Ciências Ambientais, Federal University of Amapá, Macapá, Amapá, Brazil

*Corresponding Author: Darren Norris, Email: dnorris75@gmail.com

Authors' Contribution statement (CRediT):

AB: Data Curation (supporting); Formal Analysis (lead); Investigation (supporting);

Visualization (lead); Writing - original draft (lead); Writing - review and editing (equal) JPG: Conceptualization (equal); Funding Acquisition (equal); Writing - review and editing

23 (equal)

24 DN: Conceptualization (equal); Funding Acquisition (equal); Methodology (equal); Investigation

25 (supporting); Data Curation (equal); Formal Analysis (supporting); Visualization (supporting); 


\section{Abstract}

29 1. Construction of hydropower dams is associated with negative impacts on biodiversity, yet there remains a lack of robust scientific evidence documenting the magnitude of these impacts particularly across highly biodiverse tropical waterways. Hydropower expansion is an increasing threat to the Endangered yellow-spotted river turtle (Podocnemis unifilis) across its tropical

33 South American range.

$342 . \quad$ Yellow-spotted river turtle nesting-areas were monitored as an indicator of dry-season

35 river level changes following run-of-river dam reservoir filling. A Before-After-Control-Impact

36 (BACI) study design was used with multi-year field campaigns monitoring turtle nesting-areas

37 along $66 \mathrm{~km}$ of river upstream of the dam, separated into $33 \mathrm{~km}$ control and impact zones.

383 . The cause and extent of changes in nesting-areas were established using Generalized

39 Additive Models. Nesting-area density was evaluated in relation to: time (before versus after),

40 treatment (control versus impact), time treatment interaction (BACI), distance to the dam and

41 precipitation. The extent of changes was examined by comparing the proportion of nesting-areas

42 remaining in subzones during the four years after reservoir filling.

43 4. Dam construction generated a permanent dry season river level rise that extended more

44 than $20 \mathrm{~km}$ beyond impact assessment limits. On average the density of nesting-areas declined

$4569 \%$ (from 0.48 to 0.15 per $\mathrm{km}$ ) across $33 \mathrm{~km}$ of river directly impacted by the dam. This loss was reflected in a significant BACI interaction. Nesting-area density was not explained by

47 seasonal precipitation.

48 5. Standardized monitoring of freshwater turtle nesting-areas provided an effective means to

49 quantify impacts of hydropower developments across biodiverse yet rapidly changing waterways. The negative impacts documented in this study should be preventable by mitigation actions including habitat restoration and dry season flow regulation. Such measures would also

52 likely benefit multiple species elsewhere in tropical rivers increasingly impacted by run-of-river 53 dams.

KEY WORDS: Amazon, Before-After-Control-Impact, conservation evidence, environmental 


\section{1 | INTRODUCTION}

Mitigating dam impacts is a priority for the protection and restoration of freshwater biodiversity (Harper et al., 2021). Hydropower developments are among the most significant threats to Amazonian freshwater ecosystems (Castello \& Macedo, 2016; Latrubesse et al., 2017) and biodiversity (Dudgeon, 2019; Latrubesse et al., 2020; Vasconcelos et al., 2020). Although hydropower supplies the demand of basic human necessities, hydropower dams result in impacts that produce negative effects and feedbacks that modify freshwater ecosystem processes, functions and services (Dudgeon, 2019; Valiente-Banuet et al., 2015). Generating changes not only to biological cycles and species ecological interactions (Latrubesse et al., 2020) but also creating drastic alterations to local communities, livelihoods and cultures (Del Bene, Scheidel, \& Temper, 2018; Fearnside, 2018). Whilst negative impacts have been widely suggested, more robust evidence is required to examine the sustainability of the increasing number of dams across Brazilian Amazonia (Rodrigues dos Santos, Michalski, \& Norris, 2021; Tundisi et al., 2014).

The ecological structure and complexity of Amazonian freshwater ecosystems is a result of myriad factors operating across different temporal and spatial scales, including flood pulse (Junk \& Wantzen, 2006; Melack \& Coe, 2021) and the spatial-temporal heterogeneity of seasonal rainfall (Melack \& Coe, 2021; Reis et al., 2019; Siddiqui et al., 2021). The structure, composition, functions and services of globally important Amazonian ecosystems are threatened due to expansion of hydropower developments. To date a total of 29 dams (operational capacity $>30 \mathrm{MW}$ ) have been installed across Brazilian Amazonia (SIGEL, 2021) and another 750 are planned or under construction (Vasconcelos et al., 2020). This increase is incentivized by increasing energy demand, national and regional politics and international investment (Castello, 2021; Fearnside, 2018; Gerlak et al., 2020). Although hydropower dams require Environmental Impact Assessments, those conducted in the Brazilian Amazonia are typically characterized by localized, unstandardized and short-term biodiversity monitoring (Fearnside, 2014, 2018;

83 Pelicice \& Castello, 2021).

There is no standardized typology of dam types or sizes, which can often generate confusion in the scientific literature. For example the International Commission of Large Dams

86 (https://www.icold-cigb.org/, accessed 9 July 2021) defines a large dam as: "A dam with a height

87 of 15 meters or greater from lowest foundation to crest or a dam between 5 meters and 15 meters

88 impounding more than 3 million cubic meters", but such definitions vary in different regional 
and national contexts. "Run-of-river" dams are widely considered to generate relatively less negative impacts compared with impoundment dams as the production of energy works with the natural river flow (Gaudard, Avanzi, \& De Michele, 2018). Yet, "run-of-river" is not synonymous with small or low impact hydropower operations (Kuriqi et al., 2021), causing loss of longitudinal connectivity, habitat degradation, and simplification of the biota community, which leads to increasing need for more economically and environmentally sustainable options such as in-stream turbines across Amazonia (Chaudhari et al., 2021).

Although adoption of newer technologies is likely to reduce environmental impacts in the future (Chaudhari et al., 2021), currently a lack of evidence limits the development of effective mitigating actions of Amazonian run-of-river hydropower dams (Gerlak et al., 2020; Gomes et al., 2020). Run-of-river dams maybe constructed with or without reservoirs and range in size to large "mega-dams" such as the Belo Monte dam complex in Brazil (total installed capacity of 11,233 MW, dam heights $36-90 \mathrm{~m}$ ). The use of natural hydrological flows reduces the energy production capacity of run-of-river dams during the dry season, which is a period when supplying the energy demands can influence dry season river flow and freshwater habitats (Gierszewski et al., 2020; Latrubesse et al., 2020). Indeed, although impacts of large hydropower developments could lead to species extinction (Turvey et al., 2010) and extirpation in impacted basins (Gomes et al., 2020; Santos et al., 2020) there remains a lack of information about the impacts and responses of freshwater vertebrates to hydropower dams (He et al., 2018).

Aquatic species, like freshwater turtles are directly impacted by dam construction (Le Duc et al., 2020; Stanford et al., 2020; Tucker, Guarino, \& Priest, 2012). Although many studies focus on fishes there are few studies considering the diversity of Amazonian aquatic and semi-

112 the largest and most threatened freshwater vertebrates (Stanford et al., 2020) and are vulnerable

113 to habitat changes because their life history (Shine \& Iverson, 1995) and dependence on

114 environmental factors for embryonic development, which limits the adaptive response for 115 population recruitment against anthropic impacts (Quintana et al., 2019). Little is known about 116 the impacts of hydropower dams on freshwater turtles at temporal and spatial scales relevant to 117 develop effective management actions. As freshwater turtles are typically long-lived there is a 118 need for long-term studies to detect life-history trends (Iverson, 1991; Shine \& Iverson, 1995), 
but there are relatively few studies available documenting tropical freshwater turtle survival

120 (Rachmansah, Norris, \& Gibbs, 2020).

The Endangered (Rhodin et al., 2018) yellow-spotted river turtle (Podocnemis unifilis,

122 Figure 1) is the most widespread of six Podocnemis species found in South America, all of

123 which nest on dry land (Turtle Taxonomy Working Group, 2017). Although widespread, $P$.

124 unifilis is increasingly threatened (Rhodin et al., 2018) and without effective conservation actions

125 severe $(\geq 50 \%)$ and rapid ( $<50$ year) population losses were projected across $60 \%$ of the species

$1265.3 \mathrm{M} \mathrm{km}^{2}$ pan-Amazonian range (Norris et al., 2019). Studies emphasize the need to focus on

127 adult survival for the conservation of freshwater turtles (Páez et al., 2015; Rachmansah, Norris,

128 \& Gibbs, 2020), but early stage (e.g., egg and hatchling) is also important for the conservation

129 and recovery of freshwater turtles (Rachmansah, Norris, \& Gibbs, 2020) and P. unifilis

130 populations (Norris et al., 2019). Nesting patterns are useful to understand responses of

131 chelonian populations (Iverson, 1991) to environmental disturbance because nesting is key for

132 female turtles to guarantee their survival and sustain populations (Refsnider \& Janzen, 2010).

133 Changes in dry season flood pulse and/or flow rates, could therefore result in negative impacts

134 on Podocnemis populations due to changes in nest site selection and hatchling success

135 (Eisemberg et al., 2016; Norris, Michalski, \& Gibbs, 2020).

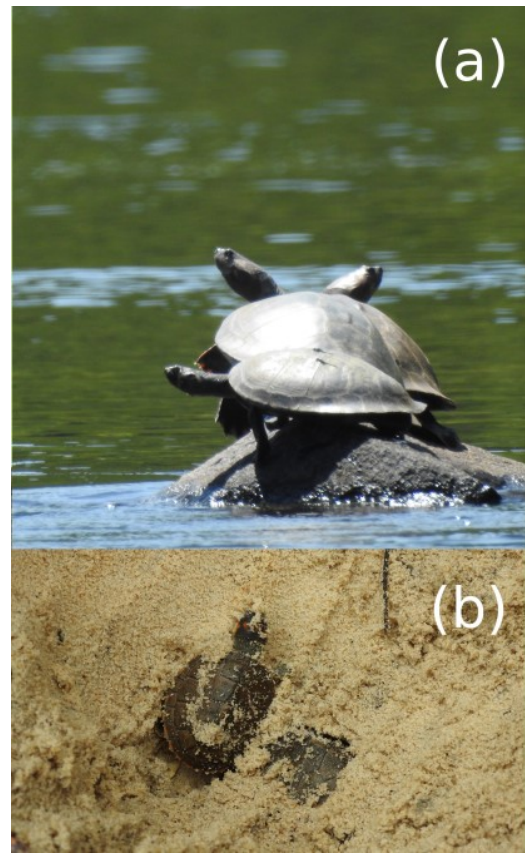

Figure 1. Study species. Adult and hatchlings of the yellow-spotted river turtle: (a) Adult

138 females basking and (b) Hatchlings emerging from a nest laid in the sand of a riverside nesting139 area. 
Freshwater turtle nesting-areas are important for multiple Amazonian species not only for the turtles themselves (Campos-Silva et al., 2018). The seasonal reduction in river flow exposes river banks and islands, creating ephemeral habitats that represent essential seasonal resources

144 for both freshwater and terrestrial biodiversity across Amazonia (Castello, 2021; Junk \& 145 Wantzen, 2006; Melack \& Coe, 2021). These seasonal habitats are used not only by diverse 146 oviparous wildlife (Campos-Silva et al., 2018; Campos-Silva et al., 2021) and their predators (da

147 Costa Reis et al., 2021), but can also facilitate movements e.g. as stepping-stones to cross rivers

148 (Mamalis et al., 2018), and provide locations for reproductive/territorial behaviours (Michalski et 149 al., 2021).

150 In the present study $P$. unifilis nesting areas were monitored as a biologically relevant 151 indicator of river level changes following run-of-river dam reservoir filling. The objective was to 152 expand on previous results from the first year after construction of a large run-of river dam 153 (Norris, Michalski, \& Gibbs, 2018), comparing annual numbers of turtle nesting-areas to 154 examine if upstream patterns in the submersion of nesting-areas remained consistent after four years post-reservoir filling and to test the influence of potentially confounding variables

156 (seasonal precipitation). For the first time establishing robust causal evidence documenting the 157 extent of impacts of a run-of-river dam reservoir on an Endangered vertebrate species in the 158 Amazon. The study documents permanent dry season changes beyond established limits with 159 implications for global efforts to monitor free flowing rivers (Grill et al., 2019). The findings are 160 used to suggest important mitigation actions that are likely to benefit multiple species in highly diverse Amazonian rivers increasingly impacted by run-of-river dams.

\section{2 | MATERIALS \& METHODS}

\section{1 | Study area}

This study was conducted in the Araguari river basin, eastern equatorial Amazonia, in the central region of the Brazilian State of Amapá (Figure 2). The basin includes rivers classified as "clear water" (Junk et al., 2015). The Araguari River has an extension of 560 km (Ziesler \& Ardizzone, 1979) and rises in the Guiana Shield at the base of the Tumucumaque uplands, bifurcates and

171 [“Am” Tropical monsoon (Kottek et al., 2006)], with a dry season from September to November 
172 ( $<150 \mathrm{~mm}$ of monthly rain) and the rainy season (>300 $\mathrm{mm}$ of monthly rain) from February to 173 April (Supporting Information S1).

174 There are currently three dams with a combined installed capacity of $549 \mathrm{MW}$ (78, 252 and

$175219 \mathrm{MW}$ ) along an $18 \mathrm{~km}$ stretch of the Araguari River (ANEEL, 2020; EDP-Brasil, 2018;

176 INESC, 2017). Coaracy Nunes was the first dam installed along the Araguari River in 1975 and

177 was also the first dam in the Brazilian Amazon. The present study focuses on the $219 \mathrm{MW}$

178 Cachoeira Caldeirão dam $\left(51^{\circ} 17^{\prime} \mathrm{W}, 0^{\circ} 51^{\prime} \mathrm{N}\right)$, which became operational in 2016 and is the most

179 recent and most upstream dam in the Araguari river. Cachoeira Caldeirão is a large run-of-river 180 dam, with a height of $20.6 \mathrm{~m}$ and length of $730 \mathrm{~m}$ (EDP-Brasil, 2018). It was installed and is 181 currently operated by the Empresa de Energia Cachoeira Caldeirão S.A, which is a joint venture 182 between China Three Gorges Brasil and Energias de Portugal- Brasil S.A (EDP-Brasil, 2018). 183 Upstream of the dam, the Araguari River flows between two sustainable-use conservation areas 184 (Figure 2): Amapá National Forest ("Floresta Nacional do Amapá" - FLONA) and the Amapá 185 State Forest (“Floresta Estadual do Amapá” - FLOTA).

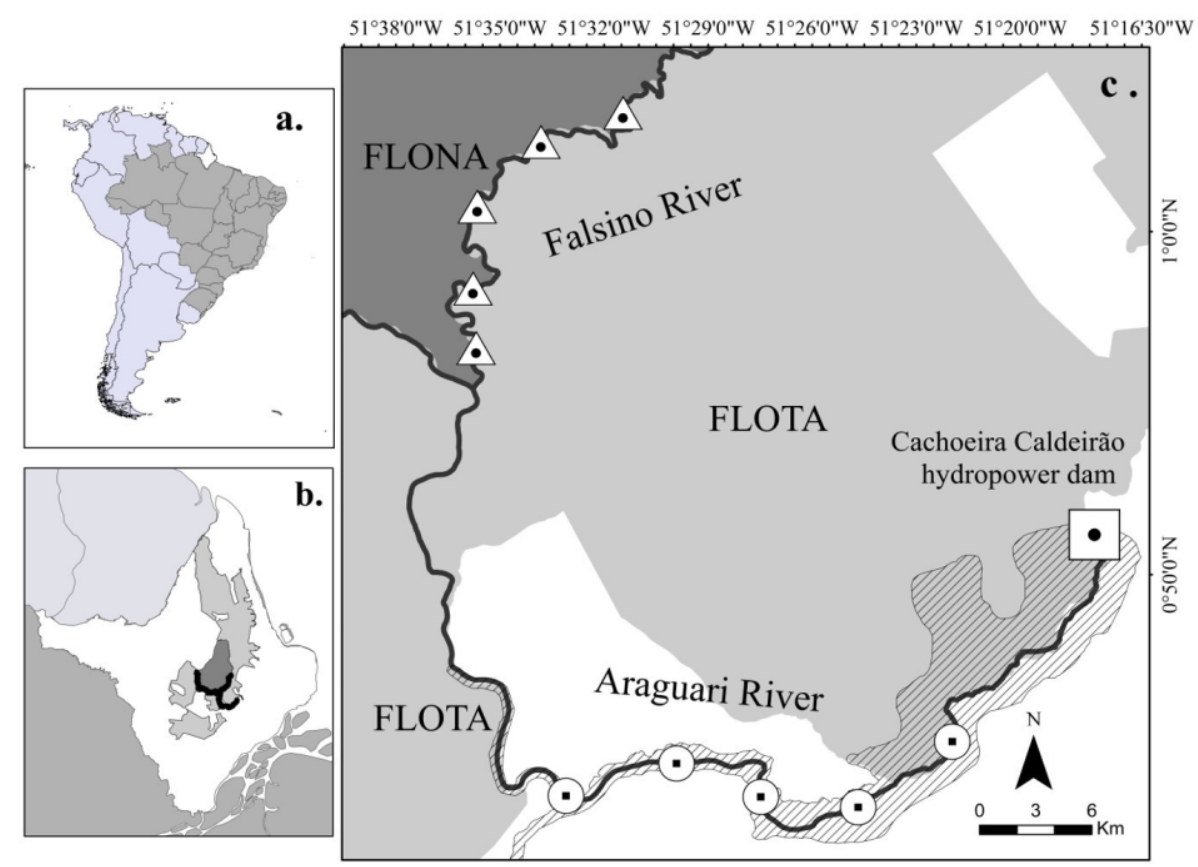

Figure 2. Study area. a. State of Amapá in Brazil. b. Location of the study river (black line) within Amapá. c. Location of the Impact (circles) and Control (triangles) subzones upstream of the Cachoeira Caldeirão hydropower dam (square). Hashed shading is the area of direct impact identified in the Environmental Impact Assessment. Grey shaded polygons show the protected areas: Amapá National Forest ("Floresta Nacional do Amapá" - FLONA) and the Amapá State 192 Forest ("Floresta Estadual do Amapá” - FLOTA). 


\section{2 | Nesting-area surveys}

194 Monthly boat surveys were conducted to locate nesting-areas from September to December, which corresponds to the nesting season of P.unifilis in the study area (Norris, Michalski, \& Gibbs, 2018). Surveys were carried out upstream of the Cachoeira Caldeirão hydropower dam

197 before (2011 and 2015) and after $(2016,2017,2018,2019)$ reservoir filling. Sampling and data 198 collection in 2019 followed that from previous years $(2011,2015,2016,2017$ and 2018) as

199 described previously (Michalski et al., 2020; Norris, Michalski, \& Gibbs, 2018; Norris,

200 Michalski, \& Gibbs, 2020; Quintana et al., 2019). Here the standardised sampling methods are 201 briefly summarised. Areas suitable for turtle nesting (Figure 3) were located and identified based 202 on the following features: areas $>1 \mathrm{~m}^{2}$, with exposed sand/gravel substrates, raised above river 203 level, without being waterlogged to a depth of $15 \mathrm{~cm}$ (Norris, Michalski, \& Gibbs, 2018). For 204 each nesting-area it was recorded whether the surface was exposed or submerged below water. 205 Nesting-areas that were flooded subsequent to exposure/nesting were identified as flooded and 206 not included as "submerged" i.e. submerged includes only those nesting-areas that were never 207 exposed during the nesting season (September to December).

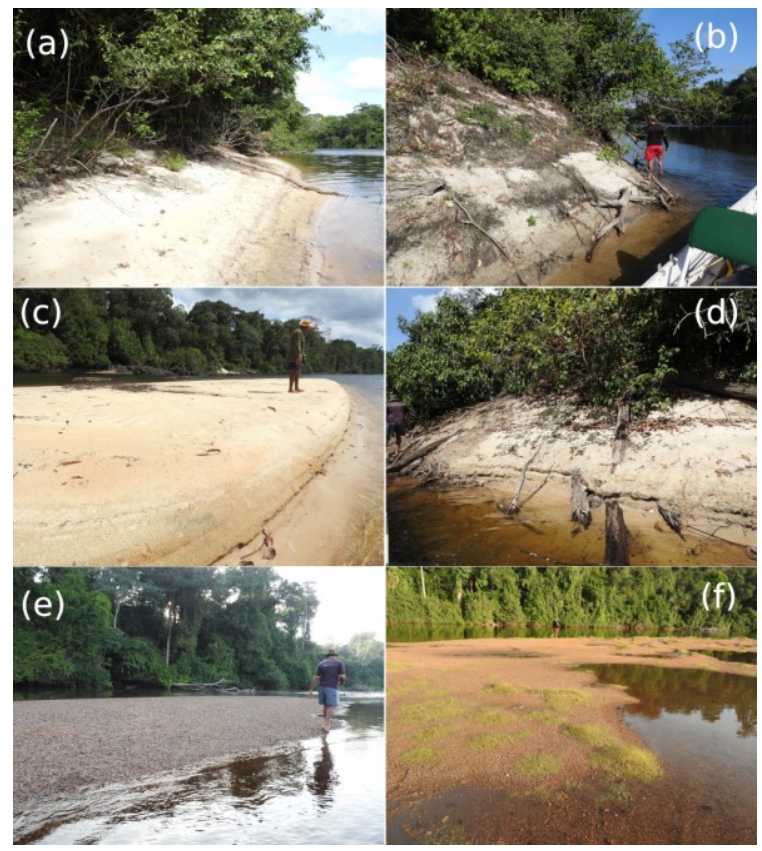

Figure 3 Nesting-areas. Representative yellow-spotted river turtle (Podocnemis unifilis) nesting-areas examples showing $(a, b)$ : potential nesting areas with suitable habitat conditions for nesting, but no nests (i.e., locations that females could use for nesting but nests were not found); (c, d): actual nesting areas (i.e., locations where females actually nested), and (e, f): unsuitable 213 habitat areas for nesting (i.e., where substrate conditions were not appropriate for females to 214 nest). Reproduced from Norris, Michalski, and Gibbs (2018). 
To confirm the presence of turtle nests, searches were conducted by a team of three

217 observers. One member was a local resident with over 30 years of knowledge of nesting-areas.

218 Searches were made at a standardized walking speed (mean $0.8 \mathrm{~km}$ per hour, range 0.2-1.3) with

219 time spent searching areas ranged from 10 to 97 minutes depending on the size of the area

220 (Norris, Michalski, \& Gibbs, 2018; Quintana et al., 2019). Nests were located by following turtle

221 tracks on the substrates (sand/gravel) and systematic substrate searches with a wooden stick

222 (Norris, Michalski, \& Gibbs, 2018; Quintana et al., 2019). Nests that had been depredated were

223 identified by the presence of broken eggshells outside the nest, disturbed/uncovered nests and the

224 presence of excavation marks (Escalona \& Fa, 1998). The presence of all nests was considered

225 including those depredated by humans or wildlife.

\section{3 | Explanatory variables}

228 Distance from dam and precipitation were used to explain temporal and spatial patterns in 229 nesting-area density. Distance to the hydropower dam was calculated along the river network 230 using the riverdist package (Tyers, 2020) in $\mathrm{R}(\mathrm{R}$ Core Team, 2020). Because rainfall is an 231 important determinant of annual and seasonal variation in Amazonian river flow rates (Melack \& 232 Coe, 2021; Siddiqui et al., 2021) such that elevated precipitation during the months preceding 233 nesting could result in nesting-areas remaining submerged. The total and standard deviation of 234 precipitation (PPT) during each of the three months (July, August and September) prior to the 235 peak of the nesting season in the six monitored years was calculated (Supporting Information 236 S1). Precipitation data was obtained from a weather station (Serra do Navio, id: 8052000, $\left.23752^{\circ} 00^{\prime} \mathrm{W}, 0^{\circ} 53^{\prime} \mathrm{N}\right)$, located approximately $115 \mathrm{~km}$ upstream from the Cachoeira Caldeirão dam; 238 data available in the virtual database of the Brazilian National Water Agency ("Agência

239 Nacional de Águas": http://www.snirh.gov.br/hidroweb/serieshistoricas).

\subsection{Data Analysis}

242 Two different datasets were analysed, one to establish the cause of changes in $P$. unifilis nesting243 area density (Supporting Information S2) and another to quantify the extent of changes

244 (Supporting Information S3). 


\subsection{1 | Cause of changes}

247 To establish the cause of changes the response of actual nesting-area density was modelled using

248 Generalized Additive Models [GAMs, (Marra \& Wood, 2011; Pedersen et al., 2019)]. Actual

249 nesting-areas were identified prior to reservoir filling as those where females nested in 2015

250 and/or in the previous five years [2010 - 2014, (Norris, Michalski, \& Gibbs, 2018)]; post-

251 reservoir filling the actual areas included those where females nested in the current nesting

252 season and/or during the previous five years. To represent the Before-After-Control-Impact

253 (BACI) sampling design (Smith, 2006; Underwood, 1993), the response of actual nesting-areas

254 per km was modelled by including two fixed factors, (i) before-after and (ii) control-impact and

255 their interaction, with a significant interaction indicating differences between the impacted

256 compared with the control zone associated with reservoir filling (Underwood, 1993). In this

257 study, the impacted zone (Figure 2) corresponds to $33 \mathrm{~km}$ of the Araguari River, within the

258 upstream area of direct dam impact [as defined by the Environmental Impact Assessment

259 (Ecotumucumaque, 2013; EDP energy, 2017)]. A $33 \mathrm{~km}$ stretch of the Falsino River 72 - $105 \mathrm{~km}$

260 upstream of the dam (Figure 2), which corresponds to a region with little anthropogenic

261 disturbance was established as the control zone. For the GAM analysis each zone (control,

262 impact) was divided into five subzones with an equal length of $6.6 \mathrm{~km}$ (Supporting Information

263 S2).

264

Table 1. Hypotheses and variables used to explain the impacts of a run-of-river dam on yellowspotted river turtle (Podocnemis unifilis) nesting-areas in the eastern Brazilian Amazon.

\begin{tabular}{|c|c|c|c|}
\hline Category & Variable & Hypothesis & Description \\
\hline Null & Intercept only & & $\begin{array}{l}\text { Response variable modelled } \\
\text { without predictors. }\end{array}$ \\
\hline Null & Random only & & $\begin{array}{l}\text { Includes years and subzone as } \\
\text { random effects. }\end{array}$ \\
\hline Environmental & Precipitation & $\begin{array}{l}\text { Precipitation contributes to } \\
\text { increase the river level, } \\
\text { modifying the availability } \\
\text { of nesting-areas for } P \text {. } \\
\text { unifilis. }\end{array}$ & $\begin{array}{l}\text { Continuous. Total and } \\
\text { variation (SD) in monthly } \\
\text { precipitation (July to } \\
\text { September) before peak } P \text {. } \\
\text { unifilis nesting. }\end{array}$ \\
\hline
\end{tabular}




\begin{tabular}{|c|c|c|c|}
\hline Anthropic & $\begin{array}{l}\text { Distance to the } \\
\text { hydropower dam }\end{array}$ & $\begin{array}{l}\text { Areas closer to the dam } \\
\text { have a higher negative } \\
\text { impact. }\end{array}$ & $\begin{array}{l}\text { Continuous. Distance in } \\
\text { kilometres from the } \\
\text { hydropower dam. }\end{array}$ \\
\hline Anthropic & $\begin{array}{l}\text { Zone (Control- } \\
\text { Impact) }\end{array}$ & $\begin{array}{l}\text { The impacted zone will } \\
\text { have reduced nesting-areas } \\
\text { compared with the control } \\
\text { zone. }\end{array}$ & $\begin{array}{l}\text { Categorical with two levels. } \\
\text { Impact Zone (Araguari River) } \\
\text { and Control Zone (Falsino } \\
\text { River). }\end{array}$ \\
\hline Anthropic & $\begin{array}{c}\text { When (Before- } \\
\text { After) }\end{array}$ & $\begin{array}{l}\text { After four years operating, } \\
\text { the dam has affected the } \\
\text { nesting patterns for the } P \text {. } \\
\text { unifilis. }\end{array}$ & $\begin{array}{l}\text { Categorical with two levels. } \\
\text { Years before (2011 and 2015) } \\
\text { and after }(2016,2017,2018 \\
\text { and 2019) reservoir filling. }\end{array}$ \\
\hline Anthropic & $\begin{array}{l}\text { BACI (Before- } \\
\text { After-Control- } \\
\text { Impact) }\end{array}$ & $\begin{array}{l}\text { Significant interaction } \\
\text { effect means that } \\
\text { differences in nesting } \\
\text { patterns are a direct result } \\
\text { of dam impact. }\end{array}$ & $\begin{array}{l}\text { Categorical interaction. The } \\
\text { river section and period } \\
\text { variables interact to represent } \\
\text { the Before-After-Control- } \\
\text { Impact (BACI) sampling } \\
\text { design. }\end{array}$ \\
\hline
\end{tabular}

Spatial autocorrelation was quantified using Mantel test and semi-variogram (Fortin \& Dale, 2014), which confirmed that each subzone could be considered as a spatially independent sample unit (Supporting Information 4). An information theoretic model selection approach

272 (Burnham \& Anderson, 2002) was applied to evaluate the alternative working hypothesis (Table

273 1). A set of seven models represented the working hypotheses to explain the patterns in nesting-

274 area density (Table 1). The five explanatory variables (total precipitation, standard deviation

275 precipitation, distance to the hydropower dam, before-after, control-impact and the BACI

276 interaction) were modelled separately to test their relationship with nesting-areas per kilometre.

277 All models included subzone and year as random effects to account for unexplained variation

278 that was not part of the sampling design and enable estimation of the mean and variance of the 279 global distribution of explanatory variables (Pedersen et al., 2019). An intercept only null model

280 (without predictors) and a random only model (subzone and year only) were also included for 281 comparisons. GAMs were run with Tweedie error distribution to examine which predictors 282 described changes in nesting-area density. Tweedie a probability distribution family that includes 283 the purely continuous normal and gamma distributions, the discrete Poisson distribution, and the 284 class of compound Poisson gamma distributions (Jorgensen, 1997), was used the default 285 Restricted Maximum Likelihood (REML) for all the models. 
To identify support for the seven alternative candidate models two Information Criteria were compared: Akaike Information Criterion corrected for small-sample sizes (AICc) and Bayesian Information Criterion (BIC). Model weights were calculated representing the likelihood of a given model, with evidence ratios constructed as the ratio of weights for the alternative models being compared (Burnham \& Anderson, 2002). Model selection was followed by variable selection to establish the strength and direction of individual variables. Variable selection was based on a full model (including distance, precipitation and random variables) that was evaluated using a double penalty approach to determine which variables had the strongest effect on the response variable (Marra \& Wood, 2011). As preliminary analysis suggested differences following reservoir filling, an interaction with the Before-After factor was included in each of the smooth terms for distance to dam, total precipitation and SD precipitation in this variable selection analysis.

\subsection{2 | Extent of changes}

300 The extent of changes in nesting-areas was examined by comparing the number of nesting-areas remaining in subzones during the four years after reservoir filling (2016, 2017, 2018 and 2019). As there was potential for new nesting-areas to emerge or to be lost due to natural changes in river flow both actual and potential nesting-areas were included for this analysis. Potential areas were those where environmental conditions matched those described in the literature and/or those found at the nesting-areas from 2011, but without evidence or history of nest sites (Norris, Michalski, \& Gibbs, 2018). A nesting-area could be either potential or actual during the nesting period. That is, if a potential area was identified and in a subsequent visit a nest was found then the area was counted only as actual during the nesting season. Starting in 2015 a continuous stretch of river was surveyed (completing the gap between impact and control zones initially

311 proportion of remaining nesting-areas in each of the 15 subzones was calculated. The proportion 312 of remaining nesting-areas from 2016 to 2020 was then related to the distance of the subzone 313 midpoint from the dam using a GAM with quasibinomial error family. All the analysis were 314 performed in R 4.0.1(R Core Team, 2020), with the "mgcv" package to generate GAMs (Wood, 315 2020) and the "MuMIn" package (Barton, 2020) used for model selection. 


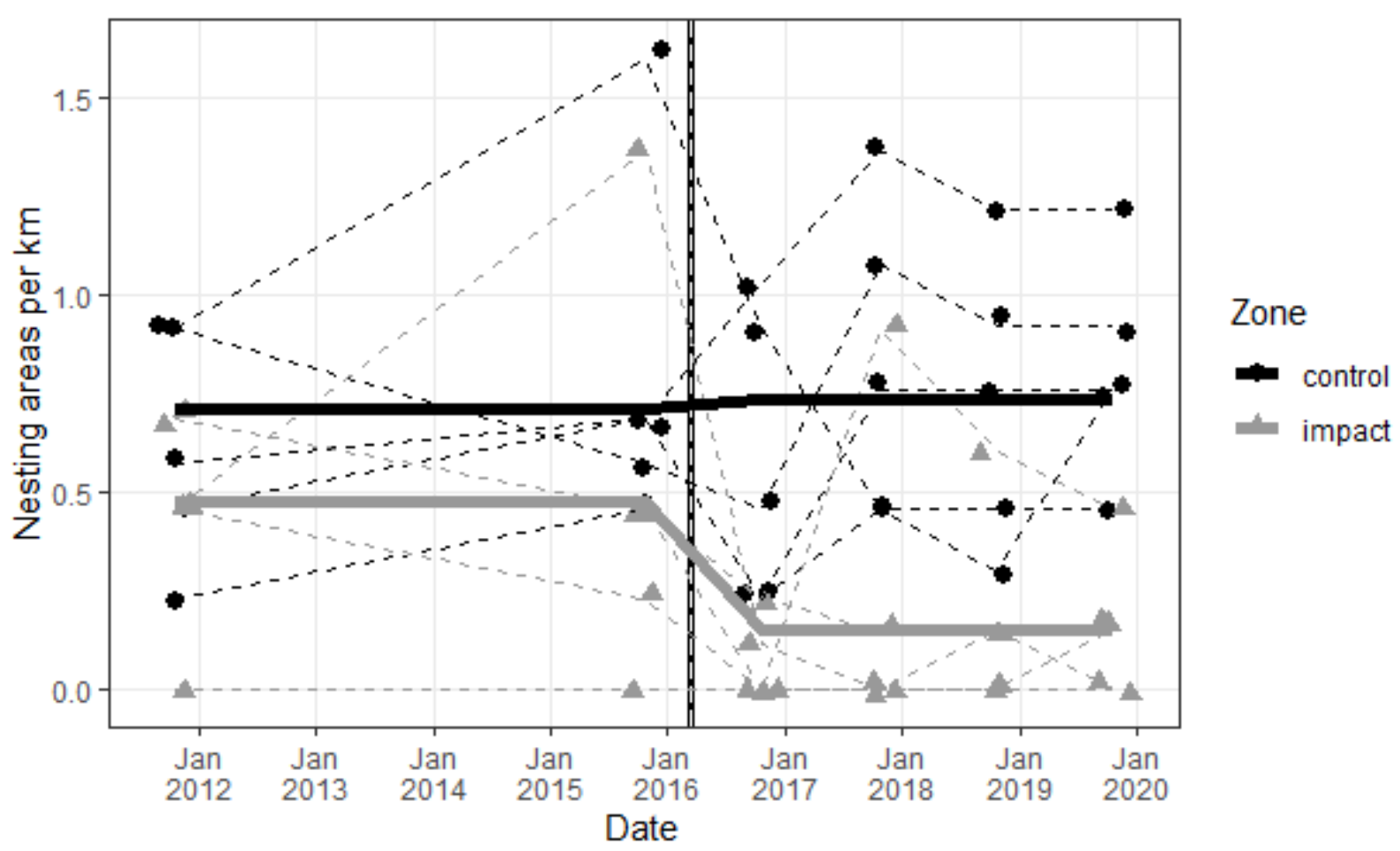

Figure 4. Nesting-areas before and after run-of-river dam construction. Observed patterns in yellow-spotted river turtle nesting-areas in the eastern Brazilian Amazon. Density of P. unifilis nesting-areas in nesting seasons before $(2011,2015)$ and after (2016 to 2019) dam reservoir filling in two zones (control and impact). Points show the number of nesting-areas per kilometre in five $6.6 \mathrm{~km}$ river subzones in each of the impact (triangles) and control (circles) zones. Dashed lines join the yearly observations for each $6.6 \mathrm{~km}$ river subzone. Solid lines (black and grey) are predictions from Generalized Additive Model. Vertical dashed line represents when the dam reservoir was filled.

Nesting-area density decreased following dam construction, with the average density dropping from 0.48 areas per $\mathrm{km}$ before to 0.15 areas per $\mathrm{km}$ after reservoir filling at the Impact zone (Figure 4). Although Control subzones tended to have more nesting-areas (Figure 4), there was variation in values between subzones and years, such that prior to reservoir filling there was no significant difference in mean nesting-area density between Control and Impact zones (GAM, $P$ $=0.279)$. In the first year following reservoir filling nesting-area density declined to 0.06 nesting-areas per kilometre in the impacted zone, with mean values remaining low in all

337 (values in the Impact subzones ranged from 0 to 0.91 nesting-areas per $\mathrm{km}$ ) there was a 
significant difference (GAM, $P=0.0061)$ in the average of nesting-area density between Impact and Control zones after reservoir filling. Indeed, following reservoir filling the observed Control zone nesting-area density was five times greater than that found in the Impact zone $(0.74$ and 0.15 areas per km, Control and Impact zones respectively).

Table 2. Explaining patterns in yellow-spotted river turtle nesting in the eastern Brazilian Amazon. Generalized Additive Models were used to explain patterns in turtle nesting-areas per $\mathrm{km}$ of river from 2011 - 2019. Models ranked according to an Information criteria approach using AICc (Akaike Information Criterion corrected for small sample sizes) and BIC (Bayesian Informative Criterion). $\mathrm{K}=$ number of parameters, $\Delta=$ delta for respective criterion values, and $w i$ $=$ the model selection weights. Models ordered by AICc values.

\begin{tabular}{|c|c|c|c|c|c|c|c|c|c|c|}
\hline \multirow{2}{*}{$\begin{array}{l}\text { Hypothesis } \\
\text { tested }\end{array}$} & \multirow{2}{*}{ Model construction } & \multirow{2}{*}{$\mathbf{K}$} & \multirow{2}{*}{$\mathbf{R}_{\text {adj }}^{2}$} & \multirow{2}{*}{$\begin{array}{l}\text { Dev. } \\
\text { Exp. } \\
(\%)\end{array}$} & \multicolumn{3}{|c|}{ AICc } & \multicolumn{3}{|c|}{ BIC } \\
\hline & & & & & AICc & $\Delta$ & $w i$ & BIC & $\Delta$ & $w i$ \\
\hline BACI & $\begin{array}{c}\mathrm{Y} \sim \mathrm{BA}: \mathrm{CI}+ \\
s\left(\text { Year }^{\dagger}\right)+s\left(\text { Subzone }^{\dagger}\right)\end{array}$ & 12 & 0.5 & 55.0 & 64.7 & 0.0 & 0.8 & 83.6 & 0.0 & 0.7 \\
\hline Before-After & $\begin{array}{c}\mathrm{Y} \sim \mathrm{BA}+ \\
s\left(\text { Year }^{\dagger}\right)+s\left(\text { Subzone }^{\dagger}\right)\end{array}$ & 12 & 0.4 & 50.1 & 69.2 & 4.5 & 0.0 & 88.0 & 4.4 & 0.0 \\
\hline Random & $\begin{array}{c}\mathrm{Y} \sim \\
s\left(\text { Year }^{\dagger}\right)+s\left(\text { Subzone }^{\dagger}\right)\end{array}$ & 12 & 0.4 & 48.0 & 71.0 & 6.2 & 0.0 & 89.7 & 6.0 & 0.0 \\
\hline Control-Impact & $\begin{array}{c}\mathrm{Y} \sim \mathrm{CI}+ \\
s\left(\text { Year }^{\dagger}\right)+s\left(\text { Subzone }^{\dagger}\right)\end{array}$ & 11 & 0.4 & 44.6 & 71.3 & 6.5 & 0.0 & 89 & 5.3 & 0.0 \\
\hline $\begin{array}{l}\text { Distance to } \\
\text { dam }\end{array}$ & $\begin{array}{c}\mathrm{Y} \sim \text { Dist. to dam }+ \\
s\left(\text { Year }^{\dagger}\right)+\mathrm{S}\left(\text { Subzone }^{\dagger}\right) \\
\mathrm{Y} \sim\end{array}$ & 11 & 0.4 & 46.2 & 71.5 & 6.8 & 0.0 & 89.8 & 6.2 & 0.0 \\
\hline Precipitation & 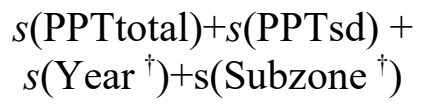 & 12 & 0.4 & 49.0 & 71.6 & 6.8 & 0.0 & 90.7 & 7.0 & 0.0 \\
\hline Intercept & $\mathrm{Y} \sim 1$ & 3 & 0.0 & 0.0 & 95.3 & 30.6 & 0.0 & 101.2 & 17.5 & 0.0 \\
\hline
\end{tabular}

$s$ : Non-parametric smooth terms

$\dagger$ Random effects

Dev. Exp. (\%): Percent of total deviance explained area density was the BACI (Table 2). All other models were only weakly supported (Table 2, 
$\Delta \mathrm{AICc}>4$ and $w i=0.0$ for models ranked by both AICc and BIC). The model including only random effects performed better compared with models including precipitation or distance to dam, with the random model having greater deviance explained and lower information criteria values (Table 2).

Table 3. Variable selection analysis. Smooth terms from a Generalized Additive Model used to explain patterns in yellow-spotted river turtle nesting-areas per km of river from $2011-2019$.

\begin{tabular}{|c|c|c|c|c|}
\hline \multirow{2}{*}{$\begin{array}{l}\text { Non-parametric } \\
\text { smooth terms }\end{array}$} & \multicolumn{2}{|c|}{ EDF } & \multicolumn{2}{|c|}{ P-value } \\
\hline & Before & After & Before & After \\
\hline Distance to the dam & 0.00 & 0.90 & 0.5951 & 0.0022 \\
\hline PPT total & 0.00 & 0.48 & 0.7239 & 0.1769 \\
\hline PPT sd & 0.84 & 0.00 & 0.0147 & 0.8809 \\
\hline Year $^{\dagger}$ & \multicolumn{2}{|c|}{0.00} & \multicolumn{2}{|c|}{0.7801} \\
\hline Subzone $^{\dagger}$ & \multicolumn{2}{|c|}{6.47} & \multicolumn{2}{|c|}{0.0049} \\
\hline $\mathrm{R}_{\text {adj }}^{2}$ & \multicolumn{2}{|l|}{0.4} & & \\
\hline Dev. Exp. (\%) & 558 & & & \\
\hline
\end{tabular}

EDF: Estimated degrees of freedom for the model terms. Values close to zero indicate no relationship with the response, close to 1 may suggest a linear relationship and values greater than 1 suggest a non-linear relationship.

$367 \dagger$ Random effects

$368 \mathrm{R}_{\text {adj: }}^{2}$ : Adjusted R squared from the model

369 Dev. Exp. (\%): Percent of total deviance explained

372 distance to the dam was only significant after reservoir filling (Table 3, $P=0.0022$, Supporting

373 Information 5). There was no relationship between nesting-area density and total precipitation.

374 Prior to reservoir filling SD precipitation was weakly related to nesting-area density (Table 3, P

$375=0.0147)$. Following reservoir filling there was no relationship between nesting-area density and

376 either of the measures of precipitation (Table $3, \mathrm{P}=0.1769$ and 0.8809 , total and SD

377 respectively). 

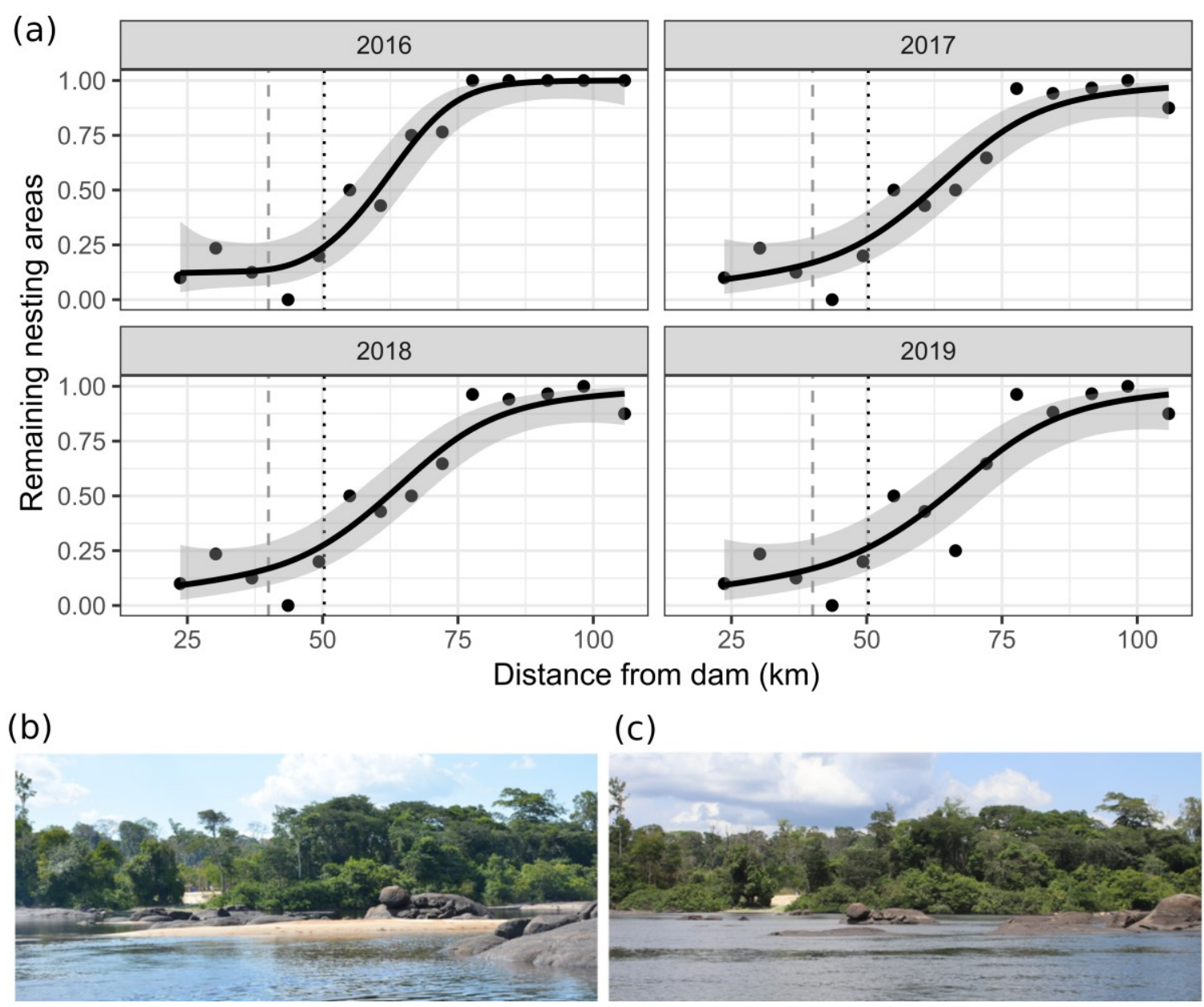

(C)

Figure 5. Extent of reservoir impacts. Remaining nesting-areas following reservoir formation at the run-of-river Cachoeira Caldeirão Dam, Amapá, Brazil. (a) The proportion of nesting-areas remaining in four years following reservoir formation was calculated along 15 equally spaced river sections (graphs generated excluding one section without nesting-areas). Dashed vertical line represents the limit (upstream river confluence) used to derive free flowing river metrics (Grill et al., 2019) and the dotted vertical line represents the limit of direct impact defined by the Environmental Impact Assessment. Lines and shaded areas are mean values and 95\% confidence intervals from Generalized Additive Models (formula $=\mathrm{y} \sim \mathrm{s}(\mathrm{x}, \mathrm{bs}=$ "cs"), family $=$ quasibinomial) that are added as a visual aid to illustrate trends in the values. Photos illustrating dry season river level and nesting-area (b) before (October 2015) and (c) after (October 2018) reservoir filling $\left(51^{\circ} 36^{\prime} 16 \mathrm{~W}, 0^{\circ} 53^{\prime} 6 \mathrm{~N}\right.$, approximately $70 \mathrm{~km}$ upstream of the Cachoeira Caldeirão dam).

Comparison of nesting-areas post reservoir filling showed significant non-linear increase in the proportion of remaining areas further from the dam in all four years post-reservoir filling $(\mathrm{GAM}, \mathrm{EDF}=8.61, \mathrm{P}<0.0001$, Figure 5). Impacts were at least $20 \mathrm{~km}$ beyond those established by the Environmental Impact Assessment and $30 \mathrm{~km}$ beyond those used to establish free flowing 
river status (Figure 5). Within $50 \mathrm{~km}$ of the dam between 76 and $100 \%$ of nesting-areas were submerged following reservoir filling, but more areas remained further from the dam (20 to $76 \%$ from 49 to $72 \mathrm{~km}$ ). There was much less variation in the control zone, with the proportion of remaining areas ranging from 87 to $100 \%$ in the five subzones beyond $75 \mathrm{~km}$ from the dam (Figure 5). Four years after reservoir filling an average of $25 \%$ of nesting-areas were submersed $75 \mathrm{~km}$ upstream of the dam some $20 \mathrm{~km}$ beyond recognized limits. This loss was at least double that experienced in the five control subzones (mean $1-9 \%$ of nesting-areas submersed, Figure $5)$.

This study provided robust evidence of a reduction in $P$. unifilis nesting-areas caused by the filling of a run-of-the-river dam reservoir in the Eastern Amazon. The availability of nesting-

410 areas was not related to seasonal precipitation, but was directly linked to the distance from the 411 hydropower dam. We suggest that mitigation actions should include habitat restoration and dry

412 season flow rate regulation to increase the availability of nesting-areas and avoid possible 413 negative impacts to $P$. unifilis populations at least within $70 \mathrm{~km}$ upstream of the dam.

The present study showed that the distance to the dam has implications for the nesting patterns of $P$. unifilis. The density of nesting-areas in the Control zone remained stable, whereas

416 in the Impact zone the reduction in the density of nesting-areas was pronounced after reservoir

417 filling. Even after four years of operation, the nesting-areas of P.unifilis in the Impact zone were 418 not restored to levels registered for the same area in the period before dam reservoir filling 419 (Norris, Michalski, \& Gibbs, 2018). The lack of nesting habitat may lead females to select poor 420 quality habitat (e.g. clay substrate) or areas with increased predation risk to nesting females or 421 nests/eggs (Quintana et al., 2019), which may contribute to increase the extinction vulnerability 422 of this species in the study region.

423 A permanent rise in dry season river levels may increase impacts of seasonal losses of 424 nesting-areas due to increasing occurrence of extreme flooding events across Amazonia 425 (Barichivich et al., 2018) that can have negative impacts on Amazonian freshwater turtle 426 populations that depend on terrestrial areas for nesting (Eisemberg et al., 2016; Norris,

427 Michalski, \& Gibbs, 2020). In addition to flooding nests, total rainfall can impact the amount of 
428

429

430

431

432

433

434

435

436

437

438

439

440

441

442

443

444

445

446

447

448

449

450

451

452

453

454

455

456

457

458

nesting habitat available or the availability of some other limiting resource, as demonstrated for Batagur kachuga where it had a significant negative correlation with nest number and monsoon magnitude (Sirsi et al., 2017). In contrast to Sirsi et al. (2017), the present study found that seasonal precipitation was not related to the density of nesting areas over seven years of nestingarea monitoring along more than $100 \mathrm{~km}$ of river.

The submersion of nesting-areas agrees with previous studies that suggest the impacts of run-of-river dam reservoirs are likely underestimated (Norris, Michalski, \& Gibbs, 2018). Runof-river dams are known to alter flow rates upstream of the reservoir, reducing flow rates which can lead to increasing upstream river levels and water residence times (Almeida et al., 2019). Although run-of-river dams are considered to generate hydropower with relatively reduced impacts (Gaudard, Avanzi, \& De Michele, 2018), due to highly seasonal rainfall and river flow rates the vast majority of Amazonian run-of-river dams include reservoirs e.g. Belo Monte (Hall \& Branford, 2012) and can therefore generate drastic impacts on flowrates (Mendes et al., 2021). The results of the present study suggest that the dry season extent of river level rise is permanently at least $20 \mathrm{~km}$ beyond recognized limits. This finding that impacts extended beyond those of the environmental impact assessment adds to the growing consensus regarding the link between superficial impact assessments and a lack of social and environmental sustainability of Amazonian hydropower developments (Fearnside, 2014, 2018; Gerlak et al., 2020).

In the case of the Cachoeira Caldeirão dam, the environmental impact assessment (EIA) of reservoir impacts was based on simplistic predictions without any consideration of uncertainty or seasonality. The spatial extent of impacts was predicted based on a single value for a "normal" flood quota of $58.3 \mathrm{~m}$, not considering the range to the estimated maximum flood quota of 59.6 m (Ecotumucumaque, 2013). As such, impacts beyond those indicated in the EIA are to be expected and must be included in conservation management and mitigation actions. The comparison with global scale estimates (Grill et al., 2019) suggests that the impact of dams could be widely underestimated for biodiverse and complex tropical rivers. The analysis was based on a single species and tropical rivers include innumerable biodiversity that remains to be evaluated. Indeed, even for arguably the most intensely studied group (fishes) a recent review established a lack of results documenting impacts generated by run-of-river dams in tropical regions (Turgeon et al., 2021). Therefore, there is an urgent need for studies to generate more robust evidence documenting the biological impacts of hydropower developments in tropical regions. 
Quantifying changes in nesting-areas is important but additional studies needed to establish direct link with species population viability. For example, boat surveys could also provide an effective means of monitoring female populations during the nesting season as they tend to bask on logs and rocks (Conway-Gómez, Reibel, \& Mihiar, 2014; Coway-Gomez, 2007). Although still incipient, studies show that boat surveys can be used to monitor freshwater turtle abundances at a local scale [e.g. 6 km surrounding islands in Florida (Breininger et al., 2019)] and more widely [e.g. P. unifilis populations along $>50 \mathrm{~km}$ of rivers in Bolivia (Coway-Gomez, 2007; Yapu-Alcázar et al., 2018) and Peru (Norris et al., 2011; Pitman et al., 2011)]. As $P$. unifilis is widespread and ubiquitous across Amazonian river basins (Norris et al., 2019; Turtle Taxonomy Working Group, 2017), integrating nesting-area surveys with river based population monitoring could therefore provide robust empirical estimates to parameterize population viability analysis in basins and rivers impacted by hydropower developments across Amazonia.

A robust understanding of hydropower development impacts is necessary to enable

472 development of effective minimization and mitigation actions. Among the short- and medium473 term mitigation measures that should be adopted are: i) creation of new turtle nesting habitat, ii)

474 improved dry season regulation of water discharge by the hydropower plant to enable upstream

475 river levels to drop during four months needed for turtle nesting and hatching (September,

476 October, November and December in the study region) and iii) integrated monitoring and 477 conservation of turtle populations, particularly with the local community. Although the impacts

478 and the recommendations listed above were shared with the operating company in 2018, years of

479 meetings and negotiations have resulted in no interventions or financial recompense by the

480 company to address the impacts that went beyond limits established in the Environmental Impact

481 Assessment. The lack of conservation and restoration projects materialising as mitigation actions

482 limits the ability of this run-of river dam to be considered as a sustainable source of energy 483 generation.

484 The results show that monitoring nesting-areas provides useful insight into the impacts of 485 dams. Considering the widespread distribution of $P$. unifilis such monitoring can be widely 486 applied to enable basin level evaluations of river level changes following dam construction.

487 Continuous and standardized monitoring of nesting areas can be implemented and strengthened 488 through the establishment of community management programs (Harju, Sirén, \& Salo, 2018; 489 Rivera et al., 2021). Several studies have shown the benefits of this type of management focused 
490 on the conservation of nesting areas and maintaining the recruitment of turtle populations

491 (Campos-Silva et al., 2018; Norris, Michalski, \& Gibbs, 2020; Norris et al., 2019). In addition,

492 these actions bring conservation co- benefits for other species, for example migratory waterfowl,

493 which also use the turtles' nesting habitat (Campos-Silva et al., 2021). Similarly, local

494 communities can also obtain economic and food benefits (Harju, Sirén, \& Salo, 2018; Rivera et

495 al., 2021).

\section{CONCLUSION}

498 Hydropower developments should adopt flow regulation schemes that are compatible with the 499 persistence of impacted species. Assessments of the spatial extents of hydropower development

500 impacts must consider relevant range of flood quota values in order to avoid underestimation of

501 impacts to local and regional biodiversity. Due to their social and cultural importance freshwater

502 turtles represent conservation "flagship" species across tropical South America. Monitoring

503 nesting-areas is straight forward and should be a regional/ basin wide focus to not only rapidly

504 identify impacts but also develop effective mitigation actions for biodiversity conservation in

505 tropical rivers impacted by hydropower dams. Any management program to be implemented

506 must be designed considering the social, economic and environmental characteristics of each

507 region, as well as having the participation of the local population, research groups, government

508 and companies in charge of dam management.

509 


\section{ACKNOWLEDGEMENTS}

512 We are grateful to Alvino Pantoja and Gilberto Souza dos Santos for their invaluable assistance

513 during field-work in 2019. We are also grateful to the field assistants, students and volunteers

514 who have helped to collect data during the previous nesting seasons. We would like to thank the

515 Universidade Federal do Amapá and the Instituto Chico Mendes de Conservação da

516 Biodiversidade (ICMBio) for providing logistical support; IBAMA for authorization

517 (IBAMA/SISBIO permit 49632-1) to conduct research around FLONA.

\section{CONFLICT OF INTEREST}

520 The authors declare no conflict of interest.

\section{FUNDING}

523 This study was funded by The United States National Academy of Sciences and the United

524 States Agency for International Development through the Partnership for Enhanced Research

525 (http://sites.nationalacademis.org/pga/peer/index.htm), award number AID-OAA-A11-00012 to

526 Darren Norris, James P. Gibbs and Fernanda Michalski. Andrea Bárcenas was financed with a

527 scholarship provided by Coordenação de Aperfeiçoamento de Pessoal de Nível Superior

528 (CAPES). FM receives a productivity scholarship from CNPq (Grant: Process 302806/2018-0)

529 and was funded by CNPq (Grant: 403679/2016-8). 


\section{REFERENCES}

Almeida, R. M., Hamilton, S. K., Rosi, E. J., Arantes, J. D., Barros, N., Boemer, G., et al. (2019). Limnological effects of a large Amazonian run-of-river dam on the main river and drowned tributary valleys. Scientific Reports, 9(1), 16846. doi:10.1038/s41598-01953060-1

ANEEL. (2020). Listas de Usinas por estado/Municipio. Retrieved from https://app.powerbi.com/view?r=eyJrIjoiNjc4OGYyYjQtYWM2ZC00Yj1lLWJ1YmEtYz dkNTQ1MTc1NjM2IiwidCI6IjQwZDZmOWI4LWVjYTctNDZhMi05MmQ0LWVhNG U5YzAxNzB1MSIsImMiOjR9

Barichivich, J., Gloor, E., Peylin, P., Brienen, R. J. W., Schöngart, J., Espinoza, J. C., et al. (2018). Recent intensification of Amazon flooding extremes driven by strengthened Walker circulation. Science Advances, 4(9), eaat8785. doi:https://doi.org/10.1126/sciadv.aat8785

Barton, K. (2020). MuMIn: Multi-model inference. (Version 1.43.17). Retrieved from https://cran.r-project.org/web/packages/MuMIn/MuMIn.pdf

Breininger, D. R., Stolen, E. D., Breininger, D. J., \& Breininger, R. D. (2019). Sampling rare and elusive species: Florida east coast diamondback terrapin population abundance. Ecosphere, 10(8), e02824. doi:https://doi.org/10.1002/ecs2.2824

Burnham, K., \& Anderson, D. (2002). Model selection and multi-model inference (2nd ed.). New York, NY.: Springer

Campos-Silva, J. V., Hawes, J. E., Andrade, P. C. M., \& Peres, C. A. (2018). Unintended multispecies co-benefits of an Amazonian community-based conservation programme. Nature Sustainability, 1(11), 650-656. doi:https://doi.org/10.1038/s41893-018-0170-5

Campos-Silva, J. V., Peres, C. A., Hawes, J. E., Abrahams, M. I., Andrade, P. C. M., \& Davenport, L. (2021). Community-based conservation with formal protection provides large collateral benefits to Amazonian migratory waterbirds. PloS one, 16(4), e0250022. doi:https://doi.org/10.1371/journal.pone.0250022

Castello, L. (2021). Science for conserving Amazon freshwater ecosystems. Aquatic Conservation: Marine Freshwater Ecosystems, 31(5), 999-1004. doi:https://doi.org/10.1002/aqc.3615

Castello, L., \& Macedo, M. N. (2016). Large-scale degradation of Amazonian freshwater ecosystems. Global change biology, 22(3), 990-1007. doi:https://doi.org/10.1111/gcb.13173

Chaudhari, S., Brown, E., Quispe-Abad, R., Moran, E., Müller, N., \& Pokhrel, Y. (2021). Instream turbines for rethinking hydropower development in the Amazon basin. Nature Sustainability. doi:10.1038/s41893-021-00712-8

Conway-Gómez, K., Reibel, M., \& Mihiar, C. (2014). A predictive model of yellow spotted river turtle (Podocnemis unifilis) encounter rates at basking sites in lowland eastern Bolivia. Applied Geography, 53, 332-340. doi:https://doi.org/10.1016/j.apgeog.2014.06.026

Coway-Gomez, K. (2007). Effects of human settlements on abundance of Podocnemis unifilis and $P$. expansa turtles in Nortbeastern Bolivia. Chelonian Conservation and Biology, 6(2), 199-205. doi:https://doi.org/10.2744/1071-8443(2007)6[199:EOHSOA]2.0.CO;2

da Costa Reis, M., Reintjes, J. M., Chen, D., \& O’Donnell, S. (2021). Predation on nests of three species of Amazon River turtles (Podocnemis) by underground-foraging army ants (Labidus coecus). Insectes Sociaux. doi:https://doi.org/10.1007/s00040-021-00814-8 
Del Bene, D., Scheidel, A., \& Temper, L. (2018). More dams, more violence? A global analysis on resistances and repression around conflictive dams through co-produced knowledge. Sustainability Science, 13(3), 617-633. doi:https://doi.org/10.1007/s11625-018-0558-1

Dudgeon, D. (2019). Multiple threats imperil freshwater biodiversity in the Anthropocene. Current Biology, 29(19), R960-R967. doi:https://doi.org/10.1016/j.cub.2019.08.002

Ecotumucumaque. (2013). Estudo de Impacto Ambiental: Analise Socioabiental Integrada, impactos e medidas, prognosticos e programas. Retrieved from https://www.cachoeiracaldeirao.com.br/en/environment\#eis-rima

EDP-Brasil. (2018). Cachoeira Caldeirão a usina. Retrieved from https://www.cachoeiracaldeirao.com.br/en/edp-cachoeira-caldeirao-power-plant

EDP energy. (2017). Cachoeira Caldeirão Technical data (Cachoeira Caldeirão Dados Técnicos). Retrieved from http:/www.edp.com.br/geracao-renovaveis/geracao/amapa-para/uhecachoeira-caldeirao/a-usina/Paginas/dados-tecnicos.aspx

Eisemberg, C. C., Machado Balestra, R. A., Famelli, S., Pereira, F. F., Diniz Bernardes, V. C., \& Vogt, R. c. (2016). Vulnerability of Giant South American Turtle (Podocnemis expansa) nesting habitat to climate-change-induced alterations to fluvial cycles. Tropical Conservation Science, 9(4), 1-12. doi:https://doi.org/10.1177/1940082916667139

Escalona, T., \& Fa, J. E. (1998). Survival of nests of the terecay turtle (Podocnemis unifilis) in the Nichare-Tawadu rivers, Venezuela. Journal of Zoology, 244(2), 303-312. doi:https://doi.org/10.1111/j.1469-7998.1998.tb00034.x

Fearnside, P. M. (2014). Impacts of Brazil's Madeira River Dams: Unlearned lessons for hydroelectric development in Amazonia. Environmental Science \& Policy, 38, 164-172. doi:https://doi.org/10.1016/j.envsci.2013.11.004

Fearnside, P. M. (2018). Challenges for sustainable development in Brazilian Amazonia. Sustainable Development, 26(2), 141-149. doi:https://doi.org/10.1002/sd.1725

Fortin, M.-J., \& Dale, M. R. (2014). Spatial analysis: a guide for ecologists: Cambridge University Press.

Gaudard, L., Avanzi, F., \& De Michele, C. (2018). Seasonal aspects of the energy-water nexus: The case of a run-of-the-river hydropower plant. Applied Energy, 210, 604-612. doi:http://dx.doi.org/10.1016/j.apenergy.2017.02.003

Gerlak, A. K., Saguier, M., Mills-Novoa, M., Fearnside, P. M., \& Albrecht, T. R. (2020). Dams, Chinese investments, and EIAs: A race to the bottom in South America? Ambio, 49(1), 156-164. doi:https://doi.org/10.1007/s13280-018-01145-y

Gierszewski, P. J., Habel, M., Szmańda, J., \& Luc, M. (2020). Evaluating effects of dam operation on flow regimes and riverbed adaptation to those changes. Science of The Total Environment, 710, 136202. doi:https://doi.org/10.1016/j.scitotenv.2019.136202

Gomes, C. J. P., Nepomuceno Salvador, G., Casarim, R., Santos Pompeu, P., Guedes Brito, M. F., Andrade, F. R., et al. (2020). Hydropower construction plans threaten the largest Brazilian national river. Aquatic Conservation: Marine Freshwater Ecosystems, 30(12), 2464-2465. doi:https://doi.org/10.1002/aqc.3485

Grill, G., Lehner, B., Thieme, M., Geenen, B., Tickner, D., Antonelli, F., et al. (2019). Mapping the world's free-flowing rivers. Nature, 569(7755), 215-221. doi:https://doi.org/10.1038/s41586-019-1111-9

Hall, A., \& Branford, S. (2012). Development, Dams and Dilma: the Saga of Belo Monte. Critical Sociology, 38(6), 851-862. doi:https://doi.org/10.1177/0896920512440712 
623

Harju, E., Sirén, A. H., \& Salo, M. (2018). Experiences from harvest-driven conservation: Management of Amazonian river turtles as a common-pool resource. Ambio, 47(3), 327339. doi:https://doi.org/10.1007/s13280-017-0943-5

Harper, M., Mejbel, H. S., Longert, D., Abell, R., Beard, T. D., Bennett, J. R., et al. (2021). Twenty-five essential research questions to inform the protection and restoration of freshwater biodiversity. Aquatic Conservation: Marine and Freshwater Ecosystems, n/a(n/a). doi:https://doi.org/10.1002/aqc.3634

He, F., Bremerich, V., Zarfl, C., Geldmann, J., Langhans, S. D., David, J. N. W., et al. (2018). Freshwater megafauna diversity: patterns, status and threats. Diversity Distributions, 24(10), 1395-1404. doi:https://doi.org/10.1111/ddi.12780

INESC. (2017). Banco de dados de hidrelétricas na Amazônia, Cachoeira Caldeirão Retrieved from http://amazonia.inesc.org.br/banco-de-dados-hidreletricas-na-amazonia/cachoeiracalderao/

Iverson, J. B. (1991). Patterns of survivorship in turtles (order Testudines). Journal of Zoology, 69(2), 385-391. doi:https://doi.org/10.1139/z91-060

Jorgensen, B. (1997). The theory of dispersion models. . London, UK: CRC Press.

Junk, W. J., \& Wantzen, K. M. (2006). Flood pulsing and the development and maintenance of biodiversity in floodplains. In B. University of California Press (Ed.), Ecology of freshwater estuarine wetlands. (pp. 407-435). Berkeley SN.

Junk, W. J., Wittmann, F., Schöngart, J., \& Piedade, M. T. F. (2015). A classification of the major habitats of Amazonian black-water river floodplains and a comparison with their white-water counterparts. Wetlands Ecology and Management, 23, 677-693. doi:https://doi.org/10.1007/s11273-015-9412-8

Kottek, M., Grieser, J., Beck, C., Rudolf, B., \& Rubel, F. (2006). World Map of the KöppenGeiger climate classification updated. Meteorologische Zeitschrift, 15(3), 259-263. doi:https://doi.org/10.1127/0941-2948/2006/0130

Kuriqi, A., Pinheiro, A. N., Sordo-Ward, A., Bejarano, M. D., \& Garrote, L. (2021). Ecological impacts of run-of-river hydropower plants - Current status and future prospects on the brink of energy transition. Renewable and Sustainable Energy Reviews, 142, 110833. doi:https://doi.org/10.1016/j.rser.2021.110833

Latrubesse, E. M., Arima, E. Y., Dunne, T., Park, E., Baker, V. R., d'Horta, F. M., et al. (2017). Damming the rivers of the Amazon basin. Nature, 546, 363-369. doi:https://doi.org/10.1038/nature22333

Latrubesse, E. M., d'Horta, F. M., Ribas, C. C., Wittmann, F., Zuanon, J., Park, E., et al. (2020). Vulnerability of the biota in riverine and seasonally flooded habitats to damming of Amazonian rivers. Aquatic Conservation: Marine Freshwater Ecosystems, 1-14. doi:https://doi.org/10.1002/aqc.3424

Le Duc, O., Van, T. P., Leprince, B., Bordes, C., Tuan, A. N., Benansio, J. S., et al. (2020). Fishers, dams, and the potential survival of the world's rarest turtle, Rafetus swinhoei, in two river basins in northern Vietnam. Aquatic Conservation: Marine and Freshwater Ecosystems, 30(6), 1074-1087. doi:https://doi.org/10.1002/aqc.3317

Mamalis, L., Sousa da Silva, S., Bezerra Valerio, A., Norris, D., \& Michalski, F. (2018). Stepping stones facilitate river crossings by Myrmecophaga tridactyla in the north-eastern Brazilian Amazon. Edentata, 19, 30-34. doi:https://doi.org/10.2305/IUCN.CH.2018.EDENTATA-19-1.3.en 
Marra, G., \& Wood, S. N. (2011). Practical variable selection for generalized additive models. Computational Statistics Data Analysis, 55(7), 2372-2387.

Melack, J. M., \& Coe, M. T. (2021). Amazon floodplain hydrology and implications for aquatic conservation. Aquatic Conservation: Marine and Freshwater Ecosystems, 31(5), 10291040. doi:https://doi.org/10.1002/aqc.3558

Mendes, Y. A., Oliveira, R. S., Montag, L. F. A., Andrade, M. C., Giarrizzo, T., Rocha, R. M., et al. (2021). Sedentary fish as indicators of changes in the river flow rate after impoundment. Ecological Indicators, 125, 107466. doi:https://doi.org/10.1016/j.ecolind.2021.107466

Michalski, F., Martins, C. B., Rheingantz, M. L., \& Norris, D. (2021). New Scent Marking Behavior of Neotropical Otter (Lontra longicaudis) in the Eastern Brazilian Amazon. IUCN Otter Specialist Group Bulletin, 38(1), 28 -37.

Michalski, F., Norris, D., Quintana, I., Valerio, A., \& Gibbs, J. P. (2020). Substrate influences human removal of freshwater turtle nests in the eastern Brazilian Amazon. Scientific Reports, 10. doi:https://doi.org/10.1038/s41598-020-65074-1

Norris, D., Michalski, F., \& Gibbs, J. P. (2018). Beyond harm's reach? Submersion of river turtle nesting areas and implications for restoration actions after Amazon hydropower development. Peerj, 6, e4228. doi:https://doi.org/10.7717/peerj.4228

Norris, D., Michalski, F., \& Gibbs, J. P. (2020). Community based actions save Yellow-spotted river turtle (Podocnemis unifilis) eggs and hatchlings flooded by rapid river level rises. Peerj, 8, e9921. doi:https://doi.org/10.7717/peerj.9921

Norris, D., Peres, C. A., Michalski, F., \& Gibbs, J. P. (2019). Prospects for freshwater turtle population recovery are catalyzed by pan-Amazonian community-based management. Biological Conservation, 233, 51-60. doi:https://doi.org/10.1016/j.biocon.2019.02.022

Norris, D., Pitman, N. C. A., Martínez Gonzalez, J., Torres, E., Pinto, F., Collado, H., et al. (2011). Abiotic modulators of Podocnemis unifilis (Testudines: Podocnemididae) abundances in the Peruvian Amazon. Zoologia (Curitiba), 28, 343-350. doi:http://dx.doi.org/10.1590/S1984-46702011000300008

Páez, V. P., Lipman, A., Bock, B. C., \& Heppell, S. S. (2015). A plea to redirect and evaluate conservation programs for South America's Podocnemidid River Turtles. Chelonian Conservation and Biology, 14(2), 205-216. doi:https://doi.org/10.2744/CCB-1122.1

Pedersen, E. J., Miller, D. L., Simpson, G. L., \& Ross, N. (2019). Hierarchical generalized additive models in ecology: an introduction with mgcv. Peerj, 7, e6876. doi:https://doi.org/10.7717/peerj.6876

Pelicice, F. M., \& Castello, L. (2021). A political tsunami hits Amazon conservation. Aquatic Conservation: Marine Freshwater Ecosystems, 31(5), 1221-1229. doi:https://doi.org/10.1002/aqc.3565

Pitman, N. C. A., Norris, D., Gonzalez, J. M., Torres, E., Pinto, F., Collado, H., et al. (2011). Four years of vertebrate monitoring on an upper Amazonian river. Biodiversity and Conservation, 20(4), 827-849. doi:https://doi.org/10.1007/s10531-010-9982-y

Quintana, I., Norris, D., Valerio, A., Becker, F., P Gibbs, J., \& Michalski, F. (2019). Nest removal by humans creates an evolutionary trap for Amazonian freshwater turtles. Journal of Zoology, 309(2), 94-105. doi:https://doi.org/10.1111/jzo.12689

R Core Team. (2020). R: A Language and Environment for Statistical Computing (Version 4.0.1). Vienna, Austria: R Foundation for Statistical Computing. Retrieved from https://www.R-project.org/ 
714

715

716

717

718

719

720

721

722

723

724

725

726

727

728

729

730

731

732

733

734

735

736

737

738

739

740

741

742

743

744

745

746

747

748

749

750

751

752

753

754

755

756

757

758

Rachmansah, A., Norris, D., \& Gibbs, J. P. (2020). Population dynamics and biological feasibility of sustainable harvesting as a conservation strategy for tropical and temperate freshwater turtles. PloS one, 15(2), e0229689. doi:https://doi.org/10.1371/journal.pone.0229689

Refsnider, J. M., \& Janzen, F. J. (2010). Putting eggs in one basket: Ecological and evolutionary hypotheses for variation in oviposition-site choice. Annual Review of Ecology, Evolution, and Systematics, 41, 39-57. doi:https://doi.org/10.1146/annurev-ecolsys-102209-144712

Reis, V., Hermoso, V., Hamilton, S. K., Bunn, S. E., Fluet-Chouinard, E., Venables, B., et al. (2019). Characterizing seasonal dynamics of Amazonian wetlands for conservation and decision making. Aquatic Conservation: Marine Freshwater Ecosystems, 29(7), 10731082. doi:https://doi.org/10.1002/aqc.3051

Rhodin, A. G. I., Stanford, C. B., van Dijk, P. P., Eisemberg, C., Luiselli, L., Mittermeier, R. A., et al. (2018). Global conservation status of turtles and tortoises (order Testudines). Chelonian Conservation and Biology. Chelonian Conservation and Biology, 17, 135-161. doi:https://doi.org/10.2744/CCB-1348.1

Rivera, C. J., Macey, S. K., Blair, M. E., \& Sterling, E. J. (2021). Assessing Ecological and Social Dimensions of Success in a Community-based Sustainable Harvest Program. Environmental Management, 67(4), 731-746. doi:https://doi.org/10.1007/s00267-021$\underline{01425-6}$

Rodrigues dos Santos, E., Michalski, F., \& Norris, D. (2021). Understanding hydropower impacts on Amazonian wildlife is limited by a lack of robust evidence: results from a systematic review. bioRxiv, 2021.2007.2001.450737. doi:https://doi.org/10.1101/2021.07.01.450737

Santos, R. E., Pinto-Coelho, R. M., Drumond, M. A., Fonseca, R., \& Zanchi, F. B. (2020). Damming Amazon Rivers: Environmental impacts of hydroelectric dams on Brazil's Madeira River according to local fishers' perception. Ambio, 49, 1612-1628. doi:https://doi.org/10.1007/s13280-020-01316-w

Shine, R., \& Iverson, J. B. (1995). Patterns of survival, growth and maturation in turtles. Oikos, 72(3), 343-348. doi:https://doi.org/10.2307/3546119

Siddiqui, S. F., Zapata-Rios, X., Torres-Paguay, S., Encalada, A. C., Anderson, E. P., Allaire, M., et al. (2021). Classifying flow regimes of the Amazon basin. Aquatic Conservation: Marine Freshwater Ecosystems, 31(5), 1005-1028. doi:https://doi.org/10.1002/aqc.3582

SIGEL. (2021). Sistema de Informações Georreferenciadas do Setor Elétrico. Available from Agência Nacional de Energia Elétrica Sistema de Informações Georreferenciadas do Setor Elétrico Retrieved 30 March 2021, from ANEEL https://sigel.aneel.gov.br/Down/

Sirsi, S., Singh, S., Tripathi, A., McCracken, S. F., Forstner, M. R. J., \& Horne, B. (2017). Variation in reproductive output of the red-crowned roofed turtle (Batagur kachuga) and the three-striped roofed turtle (Batagur dhongoka) in the Chambal River of North India. Chelonian Conservation Biology, 16(2), 203-214. doi:https://doi.org/10.2744/CCB$\underline{1236.1}$

Smith, E. P. (2006). BACI Design. In Encyclopedia of Environmetrics. Chichester, UK: John Wiley \& Sons, Ltd.

Stanford, C. B., Iverson, J. B., Rhodin, A. G. J., van Dijk, P. P., Mittermeier, R. 1. A., Kuchling, G., et al. (2020). Turtles and tortoises are in trouble. Current Biology, 30(12), R721R735. doi:https://doi.org/10.1016/j.cub.2020.04.088 
Tucker, A. D., Guarino, F., \& Priest, T. E. (2012). Where lakes were once rivers: contrasts of freshwater turtle diets in dams and rivers of southeastern Queensland. Chelonian Conservation Biology, 11(1), 12-23. doi:https://doi.org/10.2744/CCB-0906.1

Tundisi, J. G., Goldemberg, J., Matsumura-Tundisi, T., \& Saraiva, A. C. F. (2014). How many more dams in the Amazon? Energy Policy, 74, 703-708. doi:https://doi.org/10.1016/j.enpol.2014.07.013

Turgeon, K., Trottier, G., Turpin, C., Bulle, C., \& Margni, M. (2021). Empirical characterization factors to be used in LCA and assessing the effects of hydropower on fish richness. Ecological Indicators, 121, 107047. doi:https://doi.org/10.1016/i.ecolind.2020.107047

Turtle Taxonomy Working Group. (2017). Turtles of the World: Annotated Checklist and Atlas of Taxonomy, Synonymy, Distribution, and Conservation Status (8th Ed.). In A. G. J. Rhodin, J. B. Iverson, P. P. van Dijk, R. A. Saumure, K. A. Buhlmann, P. C. H. Pritchard, \& R. A. Mittermeier (Eds.), Conservation Biology of Freshwater Turtles and Tortoises: A Compilation Project of the IUCN/SSC Tortoise and Freshwater Turtle Specialist Group. Chelonian Research Monographs 7:1-292. doi:https://doi.org/10.3854/crm.7.checklist.atlas.v8.2017

Turvey, S. T., Barrett, L. A., Hart, T., Collen, B., Yujiang, H., Lei, Z., et al. (2010). Spatial and temporal extinction dynamics in a freshwater cetacean. Proceedings of the Royal Society B: Biological Sciences, 277(1697), 3139-3147. doi:10.1098/rspb.2010.0584

Tyers, M. (2020). Package 'riverdist' (Version 0.15.3).

Underwood, A. J. (1993). The mechanics of spatially replicated sampling programmes to detect environmental impacts in a variable world. Australian Journal of Ecology, 18(1), 99-116. doi:https://doi.org/10.1111/j.1442-9993.1993.tb00437.x

Valiente-Banuet, A., Aizen, M. A., Alcántara, J. M., Arroyo, J., Cocucci, A., Galetti, M., et al. (2015). Beyond species loss: the extinction of ecological interactions in a changing world. Functional Ecology, 29(3), 299-307. doi:https://doi.org/10.1111/1365-2435.12356

Vasconcelos, L. P., Alves, D. C., da Câmara, L. F., \& Hahn, L. (2020). Dams in the Amazon: The importance of maintaining free-flowing tributaries for fish reproduction. Aquatic Conservation: Marine Freshwater Ecosystems, 1-11. doi:https://doi.org/10.1002/aqc.3465

Wood, S. N. (2020). mgcv: Mixed GAM Computation Vehicle with Automatic Smoothness Estimation (Version 1.8-34). Retrieved from https://cran.rproject.org/web/packages/mgcv/mgcv.pdf

Yapu-Alcázar, M., Tellería, L., Vaca, C., García, J., Arias, R., \& Pacheco, L. F. (2018). Bases para el manejo de la tortuga de río Podocnemis unifilis en la Reserva de la Biosfera Estación Biológica Beni, Bolivia. Ecología en Bolivia, 53(1), 52-72.

Ziesler, R., \& Ardizzone, G. D. (1979). Amazon River System. In The Inland waters of Latin America: Food and Agriculture Organization of the United Nations, COPESCAL, Doc. Téc./COPESCAL Tech.Pap. Retrieved from http://www.fao.org/docrep/008/ad770b/AD770B05.htm. 


\section{Supporting Information}

803 Supporting information 1. Precipitation. Historical series of precipitation obtained from the 804 Serra de Navio weather station (id: 8052000), available in the virtual database of the National

805 Water Agency/Agência Nacional de Águas (ANA-

806 http://www.snirh.gov.br/hidroweb/serieshistoricas).

807

808 Figure S1. Monthly trends in precipitation during the sampling years. Boxplots show means and $80995 \%$ confidence limits estimated via nonparametric bootstrap.

810

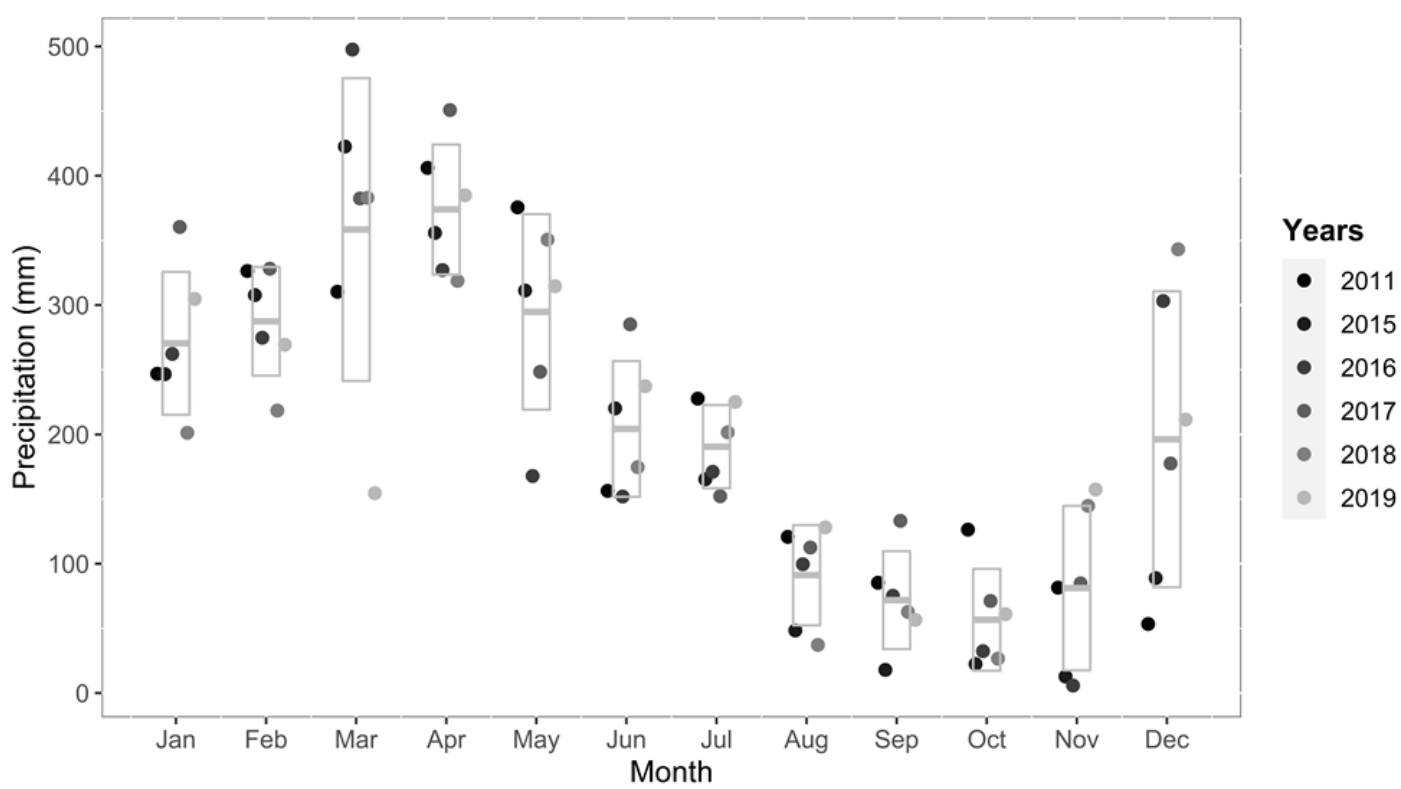


Figure S1.2. Annual precipitation patterns during the sampling years. The lines and shaded areas are the mean value and 95\% confidence intervals from Generalized Additive Models [formula $=y \sim s(x, k=10)]$ that are added to illustrate trends in the values.

818

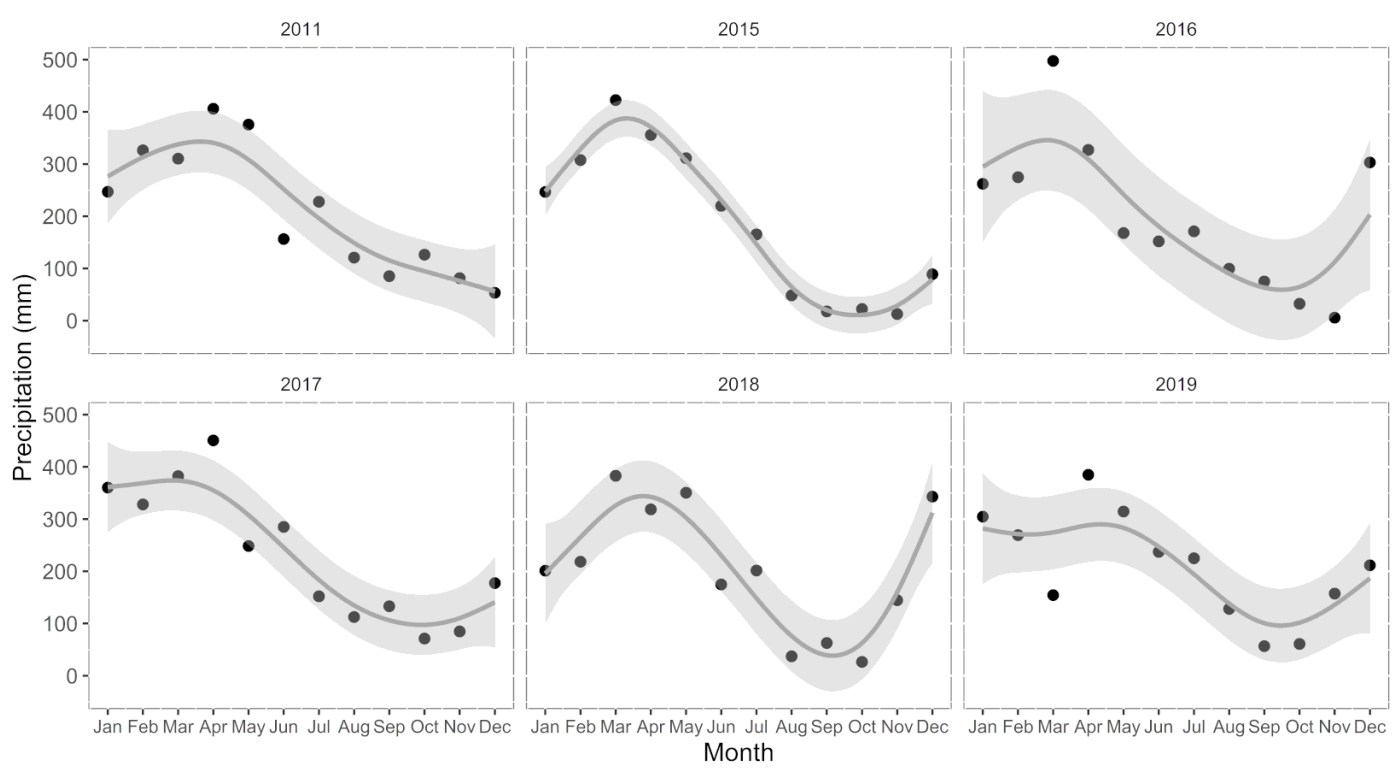

\section{References}

823 ANA. (2020). Hidroweb v3.1.1, Séries Históricas de Estações. Agência Nacional de Águas. Available at:http://www.snirh.gov.br/hidroweb/serieshistoricas. [Accessed 16 September 2020]. 
827 Supporting information 2. Data used to establish cause of changes in nesting-area density

828 (nesting-areas per $\mathrm{km}$ of river).

829

\begin{tabular}{|c|c|c|c|c|c|c|c|c|c|}
\hline Lat & Long & Zone & Subzone & When & Year & Areas_per_km & Precip_total & Precip_sd & Dist_dam_km \\
\hline 0.9434 & -51.5948 & control & 1 & before & 2011 & 0.57 & 293.2 & 24.9 & 77.7 \\
\hline 0.9722 & -51.5964 & control & 2 & before & 2011 & 0.46 & 293.2 & 24.9 & 84.41 \\
\hline 1.0123 & -51.5942 & control & 3 & before & 2011 & 0.91 & 293.2 & 24.9 & 91.58 \\
\hline 1.0438 & -51.5636 & control & 4 & before & 2011 & 0.23 & 293.2 & 24.9 & 98.24 \\
\hline 1.0577 & -51.5241 & control & 5 & before & 2011 & 0.91 & 293.2 & 24.9 & 105.8 \\
\hline 0.7529 & -51.3660 & impact & 6 & before & 2011 & 0.46 & 293.2 & 24.9 & 16.96 \\
\hline 0.7206 & -51.4113 & impact & 7 & before & 2011 & 0.46 & 293.2 & 24.9 & 23.68 \\
\hline 0.7257 & -51.4567 & impact & 8 & before & 2011 & 0.68 & 293.2 & 24.9 & 30.24 \\
\hline 0.7415 & -51.4987 & impact & 9 & before & 2011 & 0.68 & 293.2 & 24.9 & 36.92 \\
\hline 0.7257 & -51.5515 & impact & 10 & before & 2011 & 0.00 & 293.2 & 24.9 & 43.61 \\
\hline 0.9434 & -51.5948 & control & 1 & before & 2015 & 0.68 & 53.1 & 4.8 & 77.7 \\
\hline 0.9722 & -51.5964 & control & 2 & before & 2015 & 0.68 & 53.1 & 4.8 & 84.41 \\
\hline 1.0123 & -51.5942 & control & 3 & before & 2015 & 1.60 & 53.1 & 4.8 & 91.58 \\
\hline 1.0438 & -51.5636 & control & 4 & before & 2015 & 0.46 & 53.1 & 4.8 & 98.24 \\
\hline 1.0577 & -51.5241 & control & 5 & before & 2015 & 0.57 & 53.1 & 4.8 & 105.8 \\
\hline 0.7529 & -51.3660 & impact & 6 & before & 2015 & 1.37 & 53.1 & 4.8 & 16.96 \\
\hline 0.7206 & -51.4113 & impact & 7 & before & 2015 & 0.23 & 53.1 & 4.8 & 23.68 \\
\hline 0.7257 & -51.4567 & impact & 8 & before & 2015 & 0.46 & 53.1 & 4.8 & 30.24 \\
\hline 0.7415 & -51.4987 & impact & 9 & before & 2015 & 0.46 & 53.1 & 4.8 & 36.92 \\
\hline 0.7257 & -51.5515 & impact & 10 & before & 2015 & 0.00 & 53.1 & 4.8 & 43.61 \\
\hline 0.9434 & -51.5948 & control & 1 & after & 2016 & 1.03 & 113.4 & 35.01 & 77.7 \\
\hline 0.9722 & -51.5964 & control & 2 & after & 2016 & 0.23 & 113.4 & 35.01 & 84.41 \\
\hline 1.0123 & -51.5942 & control & 3 & after & 2016 & 0.91 & 113.4 & 35.01 & 91.58 \\
\hline 1.0438 & -51.5636 & control & 4 & after & 2016 & 0.23 & 113.4 & 35.01 & 98.24 \\
\hline 1.0577 & -51.5241 & control & 5 & after & 2016 & 0.46 & 113.4 & 35.01 & 105.8 \\
\hline 0.7529 & -51.3660 & impact & 6 & after & 2016 & 0.11 & 113.4 & 35.01 & 16.96 \\
\hline 0.7206 & -51.4113 & impact & 7 & after & 2016 & 0.00 & 113.4 & 35.01 & 23.68 \\
\hline 0.7257 & -51.4567 & impact & 8 & after & 2016 & 0.23 & 113.4 & 35.01 & 30.24 \\
\hline 0.7415 & -51.4987 & impact & 9 & after & 2016 & 0.00 & 113.4 & 35.01 & 36.92 \\
\hline 0.7257 & -51.5515 & impact & 10 & after & 2016 & 0.00 & 113.4 & 35.01 & 43.61 \\
\hline 0.9434 & -51.5948 & control & 1 & after & 2017 & 1.36 & 289.1 & 32.53 & 77.7 \\
\hline 0.9722 & -51.5964 & control & 2 & after & 2017 & 0.46 & 289.1 & 32.53 & 84.41 \\
\hline 1.0123 & -51.5942 & control & 3 & after & 2017 & 0.46 & 289.1 & 32.53 & 91.58 \\
\hline 1.0438 & -51.5636 & control & 4 & after & 2017 & 0.76 & 289.1 & 32.53 & 98.24 \\
\hline 1.0577 & -51.5241 & control & 5 & after & 2017 & 1.08 & 289.1 & 32.53 & 105.8 \\
\hline 0.7529 & -51.3660 & impact & 6 & after & 2017 & 0.00 & 289.1 & 32.53 & 16.96 \\
\hline 0.7206 & -51.4113 & impact & 7 & after & 2017 & 0.91 & 289.1 & 32.53 & 23.68 \\
\hline 0.7257 & -51.4567 & impact & 8 & after & 2017 & 0.15 & 289.1 & 32.53 & 30.24 \\
\hline
\end{tabular}


bioRxiv preprint doi: https://doi.org/10.1101/2021.07.29.454366; this version posted July 31, 2021. The copyright holder for this preprint (which

was not certified by peer review) is the author/funder, who has granted bioRxiv a license to display the preprint in perpetuity. It is made available under aCC-BY-ND 4.0 International license.

\begin{tabular}{lllrlrrrrr}
\hline Lat & Long & Zone & Subzone & When & Year & Areas_per_km & Precip_total & Precip_sd & Dist_dam_km \\
\hline 0.7415 & -51.4987 & impact & 9 & after & 2017 & 0.00 & 289.1 & 32.53 & 36.92 \\
0.7257 & -51.5515 & impact & 10 & after & 2017 & 0.00 & 289.1 & 32.53 & 43.61 \\
0.9434 & -51.5948 & control & 1 & after & 2018 & 1.21 & 234 & 60.52 & 77.7 \\
0.9722 & -51.5964 & control & 2 & after & 2018 & 0.46 & 234 & 60.52 & 84.41 \\
1.0123 & -51.5942 & control & 3 & after & 2018 & 0.30 & 234 & 60.52 & 91.58 \\
1.0438 & -51.5636 & control & 4 & after & 2018 & 0.76 & 234 & 60.52 & 98.24 \\
1.0577 & -51.5241 & control & 5 & after & 2018 & 0.92 & 234 & 60.52 & 105.8 \\
0.7529 & -51.3660 & impact & 6 & after & 2018 & 0.00 & 234 & 60.52 & 16.96 \\
0.7206 & -51.4113 & impact & 7 & after & 2018 & 0.61 & 234 & 60.52 & 23.68 \\
0.7257 & -51.4567 & impact & 8 & after & 2018 & 0.15 & 234 & 60.52 & 30.24 \\
0.7415 & -51.4987 & impact & 9 & after & 2018 & 0.15 & 234 & 60.52 & 36.92 \\
0.7257 & -51.5515 & impact & 10 & after & 2018 & 0.00 & 234 & 60.52 & 43.61 \\
0.9434 & -51.5948 & control & 1 & after & 2019 & 1.21 & 275 & 56.97 & 77.7 \\
0.9722 & -51.5964 & control & 2 & after & 2019 & 0.46 & 275 & 56.97 & 84.41 \\
1.0123 & -51.5942 & control & 3 & after & 2019 & 0.76 & 275 & 56.97 & 91.58 \\
1.0438 & -51.5636 & control & 4 & after & 2019 & 0.76 & 275 & 56.97 & 98.24 \\
1.0577 & -51.5241 & control & 5 & after & 2019 & 0.92 & 275 & 56.97 & 105.8 \\
0.7529 & -51.3660 & impact & 6 & after & 2019 & 0.15 & 275 & 56.97 & 16.96 \\
0.7206 & -51.4113 & impact & 7 & after & 2019 & 0.46 & 275 & 56.97 & 23.68 \\
0.7257 & -51.4567 & impact & 8 & after & 2019 & 0.00 & 275 & 56.97 & 30.24 \\
0.7415 & -51.4987 & impact & 9 & after & 2019 & 0.15 & 275 & 56.97 & 36.92 \\
0.7257 & -51.5515 & impact & 10 & after & 2019 & 0.00 & 275 & 56.97 & 43.61
\end{tabular}


832 Supporting information 3. Data used to establish extent of changes in nesting-areas, with 833 values of the proportion of nesting-areas remaining in subzones during the four years after 834 reservoir filling.

835

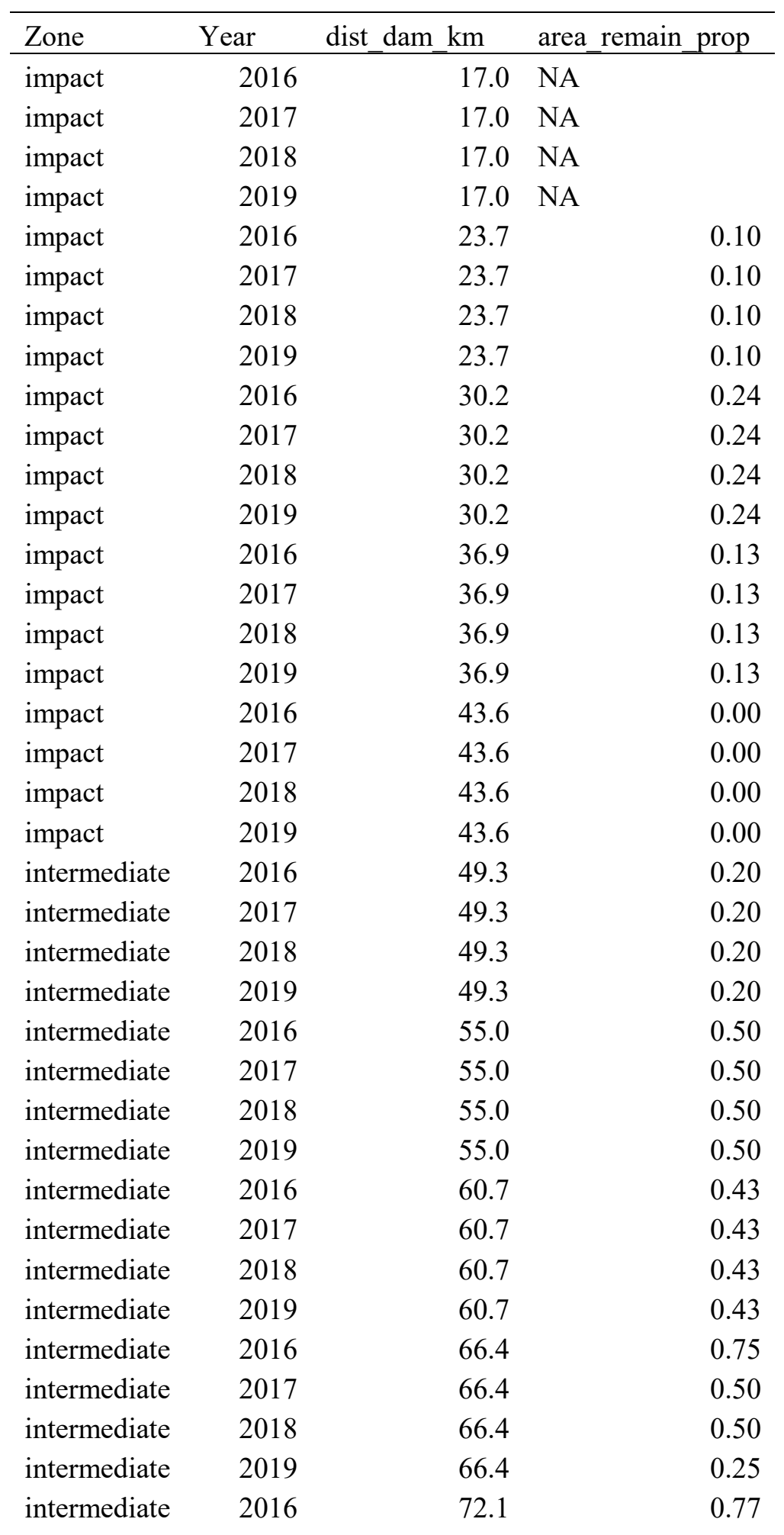


bioRxiv preprint doi: https://doi.org/10.1101/2021.07.29.454366; this version posted July 31, 2021. The copyright holder for this preprint (which was not certified by peer review) is the author/funder, who has granted bioRxiv a license to display the preprint in perpetuity. It is made available under aCC-BY-ND 4.0 International license.

\begin{tabular}{lrrr}
\hline Zone & Year & dist_dam_km & area_remain $\_$prop \\
\hline intermediate & 2017 & 72.1 & 0.65 \\
intermediate & 2018 & 72.1 & 0.65 \\
intermediate & 2019 & 72.1 & 0.65 \\
control & 2016 & 77.7 & 1.00 \\
control & 2017 & 77.7 & 0.96 \\
control & 2018 & 77.7 & 0.96 \\
control & 2019 & 77.7 & 0.96 \\
control & 2016 & 84.4 & 1.00 \\
control & 2017 & 84.4 & 0.94 \\
control & 2018 & 84.4 & 0.94 \\
control & 2019 & 84.4 & 0.88 \\
control & 2016 & 91.6 & 1.00 \\
control & 2017 & 91.6 & 0.97 \\
control & 2018 & 91.6 & 0.97 \\
control & 2019 & 91.6 & 0.97 \\
control & 2016 & 98.2 & 1.00 \\
control & 2017 & 98.2 & 1.00 \\
control & 2018 & 98.2 & 1.00 \\
control & 2019 & 98.2 & 1.00 \\
control & 2016 & 105.8 & 1.00 \\
control & 2017 & 105.8 & 0.88 \\
control & 2018 & 105.8 & 0.88 \\
control & 2019 & 105.8 & 0.88
\end{tabular}


Supporting information 4. Spatial Autocorrelation analysis. kilometre. The tests were performed in R.4.0.1 (R Development Core Team, 2021), using the "gstat" package (Pebesma \& Graeler, 2020) to calculate semi-variograms of the generalized additive model residuals (Figure S4). The semi-variograms for all models suggest no autocorrelation as uncorrelated residuals give a more or less flat semi-variogram (Fortin \& Dale, 2014).
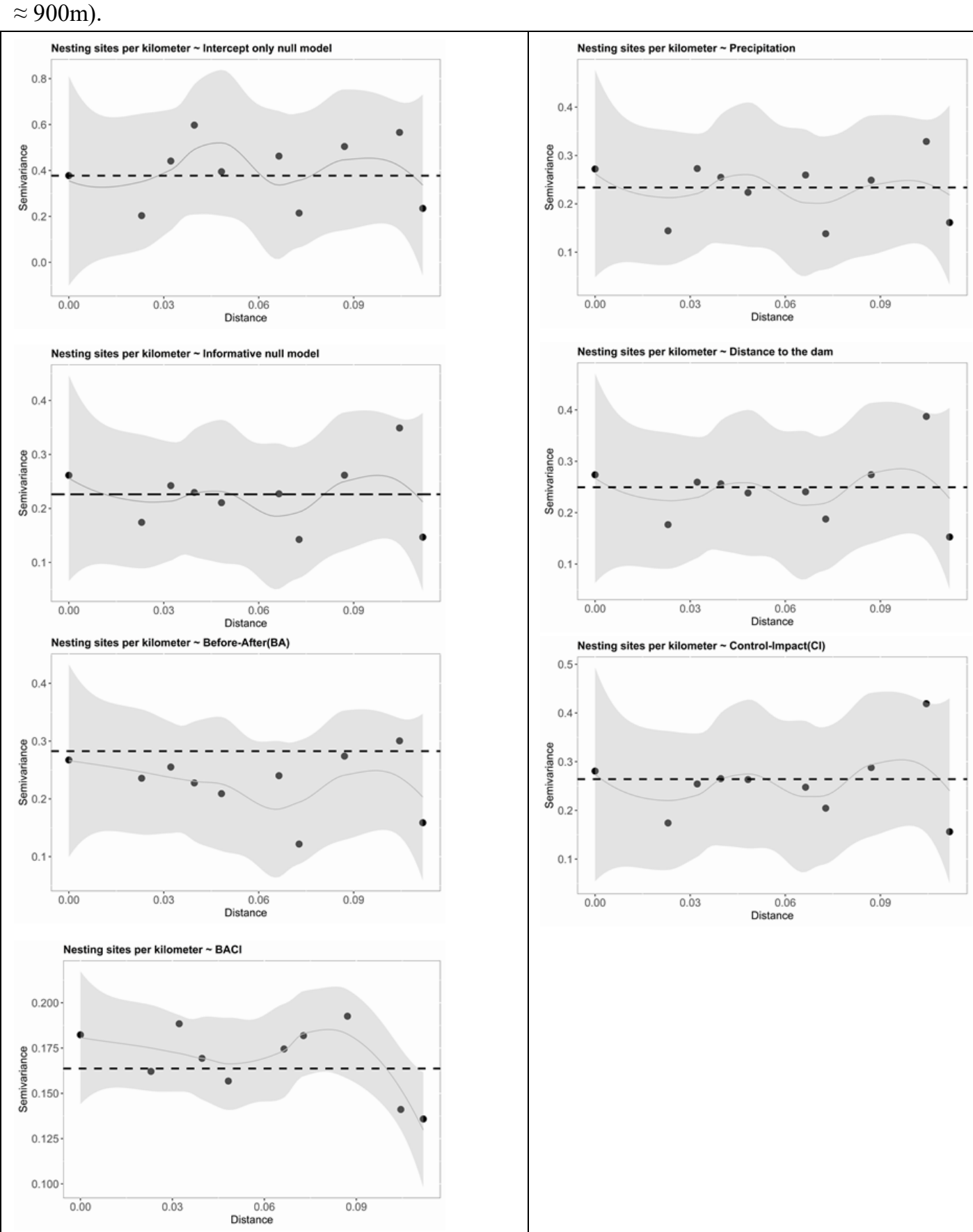


\section{References}

850 Fortin, M.-J., \& Dale, M. R. (2014). Spatial analysis: a guide for ecologists: Cambridge

$851 \quad$ University Press.

852 Pebesma, E., \& Graeler, B. (2020). gstat: Spatial and Spatio-Temporal Geostatistical Modelling, 853 Prediction and Simulation.

854 R Development Core Team. (2021). The R Project for Statistical Computing. 4.0.1. Available at: 855 https://www.r-project.org/. Vienna, Austria: R Foundation for Statistical Computer. 
857 Supporting information 5. Effects on distance to the dam and precipitation on the density of 858 nesting-areas.

859

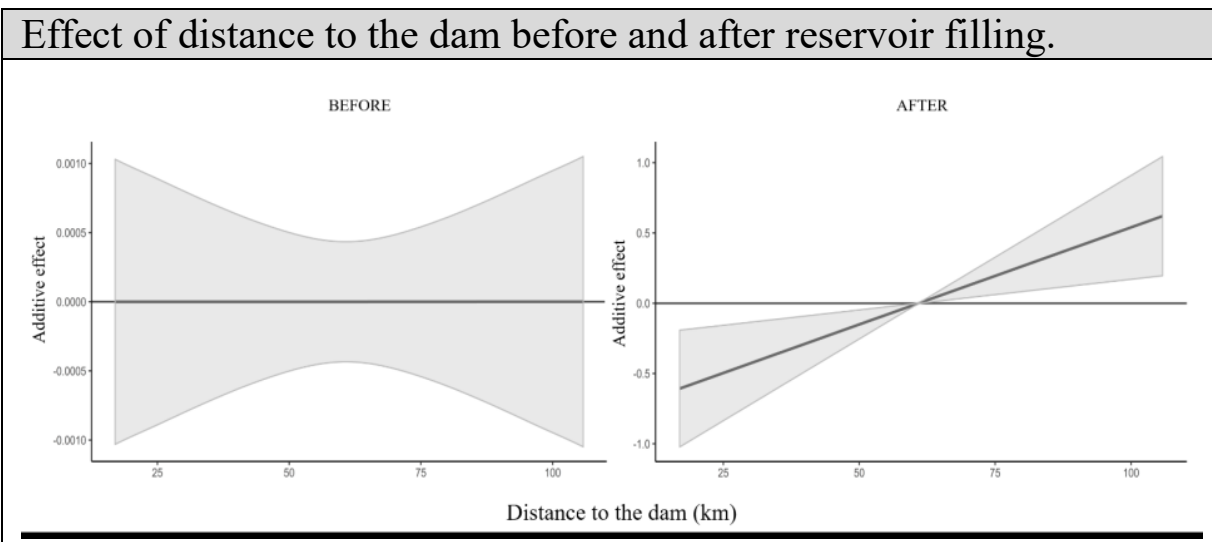

Effect of total precipitation before and after reservoir filling.

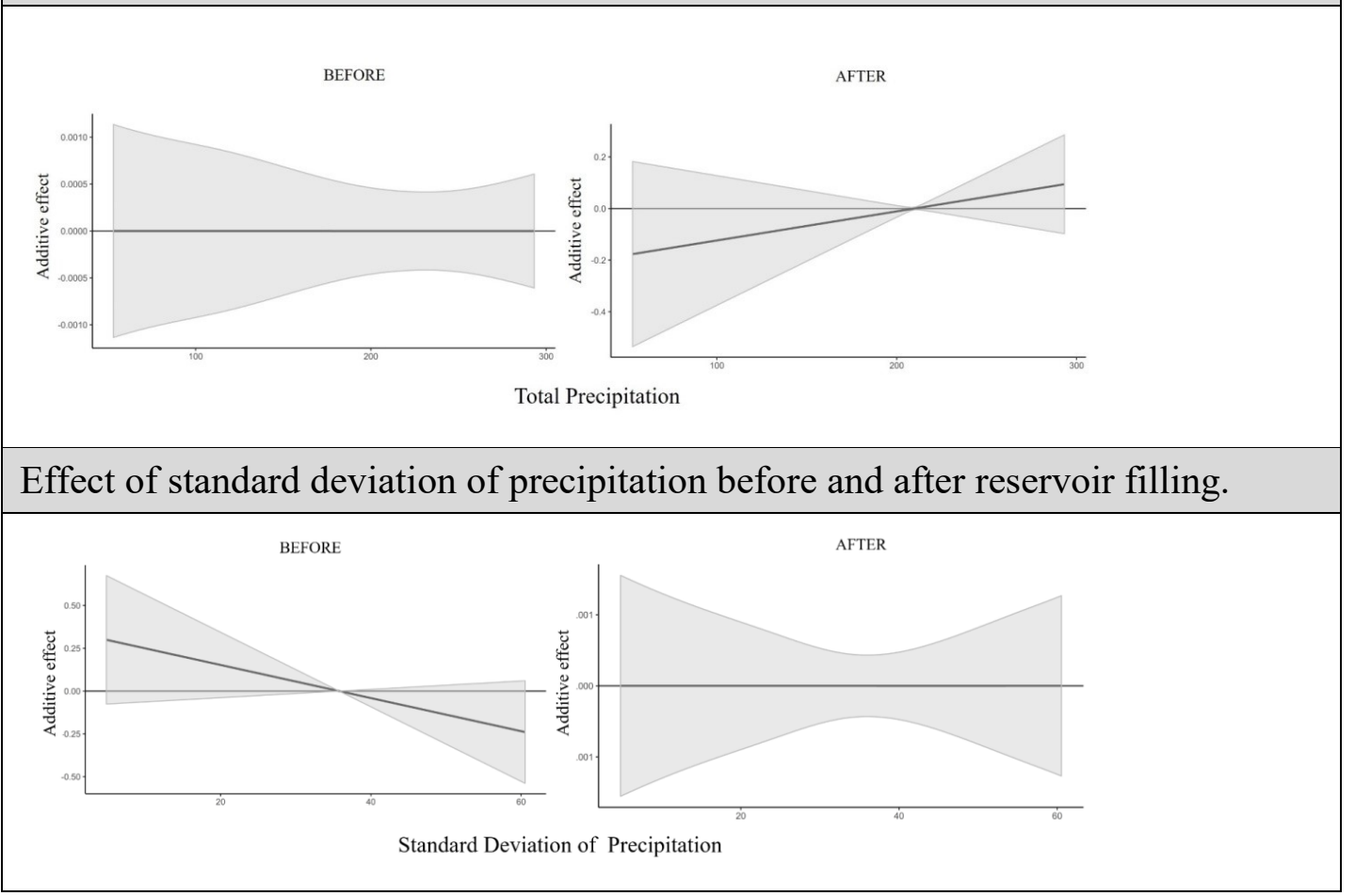

